\title{
The determinants of productivity in Chinese large and medium-sized industrial firms, 1998-2007
}

\author{
Sai Ding ${ }^{1} \cdot$ Alessandra Guariglia $^{2} \cdot$ Richard Harris $^{3}$
}

Published online: 24 October 2015

(c) The Author(s) 2015. This article is published with open access at Springerlink.com

\begin{abstract}
Using a large firm-level dataset, this paper examines total factor productivity (TFP) and its determinants in China. Our preferred GMM estimation results indicate increasing returns to scale in most industries and a usually large positive trend representing technical change. Various firm characteristics such as age, ownership, political affiliation, export behavior, liquidity, and geographic location are included in the production function. Our results show that in the context of China's institutional background, including such factors is important when estimating TFP. The average TFP growth in Chinese industries is $9.6 \%$ per annum during the period 1998-2007, and is mainly driven by firm entry. The subsector decomposition exercises show that the inter-firm resource reallocations are more prominent across industries than across provinces.
\end{abstract}

Keywords TFP · Productivity decomposition - Entry · Exit $\cdot$ Reallocation of resources $\cdot$ China

JEL Classification $\quad$ D24 $\cdot$ O14

Richard Harris

r.i.d.harris@durham.ac.uk

1 University of Glasgow, Glasgow, UK

2 University of Birmingham, Birmingham, UK

3 Durham University Business School, Mill Hill Lane, Durham DH1 3LB, UK

\section{Introduction}

Productivity is viewed as the most important long-run driver of economic growth in both economic theory and empirical research. According to Klenow and RodríguezClare (1997), total factor productivity (TFP) growth accounts for $90 \%$ of the international variation in output growth. Easterly and Levine (2001) argue that the major empirical regularities of economic growth indicate an important role for the residual rather than for factor accumulation. Productivity growth is also regarded as an important underlying reason for China's remarkable economic growth since 1978, in addition to other proximate determinates such as physical and human capital accumulation (see, for instance, Ding and Knight 2011).

In this paper, we explore the determinants of China's productivity growth using a comprehensive firm-level dataset over the period 1998-2007 (see also Brandt et al. 2012). The novelty of this paper lies at least in the following four aspects. First, when estimating TFP, we include directly in our (production function) model the determinants of TFP for which we have data (such as firm ownership, export behavior, age, political affiliation, intangible assets, liquidity, and geographic location). This is important as omission of these variables would produce biased estimates of the production function, and thus biased estimates of TFP. It is also important since we are interested not just in obtaining estimates of TFP, but also in what drives TFP in China. Second, unlike most previous studies, which rely on the method of Olley and Pakes (1996) or Levinsohn and Petrin (2003) to construct TFP, we use a system Generalized Method of Moments (GMM) estimator (Blundell and Bond 1998). We believe it is important to use this approach as many studies have shown that firms have (unmeasured) productivity advantages that 
persist over time, which need to be captured. The system GMM estimator enables us to take these fixed effects into account. Thirdly, we estimate models for different industry sub-groups to allow for differences in technologies. In other words, we avoid assuming all firms operate using a standard technology across all sectors. Lastly, we adopt the Haltiwanger approach (Foster et al. 1998) to decompose measures of productivity growth into various components that represent the impact of resource reallocation across surviving firms and the impact on productivity of the entry and exit of firms.

Our results indicate increasing returns to scale in the majority of industries and a (usually large) positive time trend representing technical change. Younger firms and firms with no political affiliation are found to have higher TFP, whereas firms with state ownership are found to have lower TFP. There exists some heterogeneous evidence among industries on the effect of high political affiliation and private ownership on TFP. Neither exports nor R\&D are found to be especially important drivers of TFP among Chinese industries. We find evidence of positive agglomeration spillovers (mitigated to some extent by negative 'costs' associated with the very largest urban areas). Firm fixed costs and liquidity are also important. Furthermore, the average TFP growth in Chinese industries is $9.6 \%$ per annum during the period of 1998-2007. In line with Brandt et al. (2012), this rapid productivity growth is mainly driven by firm entry rather than reallocation among firms in operation throughout 1998-2007 (i.e. continuers). The subsector decomposition exercises show that the inter-firm resource reallocations are more prominent across industries than across provinces.

The structure of the paper is as follows. Section 2 describes our data and empirical methodology to construct TFP. Section 3 illustrates the results of our TFP estimation, while Sect. 4 conducts the productivity decomposition using the Haltiwanger approach in order to examine the determinants of TFP growth in China. Finally, the last section concludes the paper.

\section{Existing studies for China}

There have been a number of macro-level studies on China's productivity and its determinants, which we only briefly cover since the emphasis in this paper is on microeconometric approaches (Song et al. 2011, provides a more comprehensive review of recent work in this area). Among these, Bosworth and Collins (2008) use the growth accounting approach to examine the sources of growth for China over the period 1978-2004, finding that the average annual TFP growth is $3.6 \%$ (rising from $3.0 \%$ during the period of $1978-1993$ to $6.1 \%$ during the period of
1993-2004). Using two-digit industrial level data for the period of 1998-2003, Pandey and Dong (2009) present results from a production function based regression showing that ownership restructuring and the downsizing of firms accounted for about $30 \%$ of TFP growth in China's manufacturing industries. Song et al. (2011) compute TFP as a standard Solow residual of a one-sector aggregate production function, finding an average annual growth rate of $5.9 \%$ over the period $1998-2005$; about $70 \%$ of this growth is due to reallocation from inefficient firms to more efficient ones in the manufacturing sector. In contrast, Chen et al. (2011) use the stochastic frontier approach to evaluate the productivity growth of 38 two-digit manufacturing industries in China; they find aggregate TFP growth was $6.7 \%$ during the period of 1980-2008 and that factor reallocation from less productive to more productive sectors accounted for $42 \%$ of TFP growth.

More recently, and in contrast to the approaches adopted by others, Scherngell et al. (2014) examine the role of knowledge capital in driving manufacturing TFP across 29 Chinese provinces over the period of 1988-2007. Based on a Spatial Durbin model, they find a significant effect of knowledge capital on regional TFP, which is based not only on within-region knowledge capital but also on interregional knowledge spillovers. They interpret the results as evidence for the transformation of China into a knowledgebased economy.

Turning to the micro-based evidence, Hsieh and Klenow (2009) examine the role of misallocation on aggregate productivity in China, claiming that distortions reduce China's manufacturing productivity by $30-50 \%$ relative to an optimal distribution of capital and labor across existing manufacturers for the period 1998-2005. However, it is Brandt et al. (2012) that has most relevance for the current paper. They present one of the most comprehensive and influential micro-level research on China's manufacturing TFP, by examining three possible sources for aggregate TFP growth in the manufacturing sector, i.e. firm-level productivity growth, firm entry and exit, and resource reallocation from less to more productive continuing firms. Their preferred productivity growth estimates, based on the methods of Olley and Pakes (1996) and Ackerberg et al. (2006), average $7.96 \%$ per annum for a valued-added production function, and $2.85 \%$ on a gross output basis, for 1998-2007. These are among the highest compared to other countries. Net entry accounts for over two-thirds of total TFP growth over the entire sample period. Consistent with the results of Hsieh and Klenow (2009), they find that aggregate TFP growth in manufacturing industries remains constrained by limited efficiency-enhancing input reallocations across active firms.

More recent micro-level studies include Bas and Causa (2013), who examine the effect of trade and product market 
policies in upstream sectors on productivity in downstream firms. Using ORBIS firm-level data for 2001-08, and a value-added labor productivity measure, they obtain results suggesting that removing remaining restrictions in upstream industries can bring substantive productivity gains and benefit not only firms producing in these industries but also those that use inputs from these industries. Yu (2014) also investigates the effect of trade liberalization on firm productivity in China using two highly disaggregated datasets for 2000-06. While using both an Olley and Pakes (1996) and a system GMM approach, Yu (2014) notes that the Olley-Pakes approach assumes that capital is more actively responsive to unobserved productivity, which may not be suitable for China, a labor-abundant economy with low labor costs. Yu (2014) argues that both tariff reductions and processing trade can generate productivity gains for Chinese firms.

None of these micro-level studies use multiple covariates in their models to explain what determines TFP in China; most do not include firm-level fixed effects; and none cover the broad range of industries used in the present paper. ${ }^{1}$ We build on this literature by taking all those elements into account.

\section{Data and empirical methodology}

\subsection{Data and sample}

We use data drawn from the annual accounting reports filed by industrial firms with the National Bureau of Statistics (NBS) over the period of 1998-2007. This dataset includes all SOEs and other types of enterprises with annual sales of five million yuan (about $\$ 817,000$ ) or more. These firms operate in the manufacturing, utilities and mining sectors and are located in all 31 Chinese provinces or provinceequivalent municipal cities. Since the NBS dataset does not include enterprises with annual sales below $¥ 5$ million, it is important to note that about $80 \%$ of all industrial firms are excluded from the sample. However, as shown in Brandt et al. (2012), using the full census of firms periodically carried out in China, the omitted firms only account for some $9.9 \%$ of output in 2004, and $2.5 \%$ of exports. Moreover, a comparison of 1995 NBS and Census data shows the NBS has a similar level of coverage, allowing Brandt et al. (2012) to state that “... the NBS decision rule

\footnotetext{
1 There have been a number of studies that consider productivity in specific sectors, such as electronics (Yang et al. 2013; Yang et al. 2010) and iron and steel (Sheng and Song 2013). These studies typically estimate TFP using growth accounting methods, or the Olley-Pakes methodology, with TFP being first estimated and then regressed on a set of (limited) covariates.
}

on which firms to include in their annual sample is not introducing any systematic bias in our estimates".

The dataset covers nearly 600 thousand firms, which corresponds to some 2.2 million firm-year observations. ${ }^{2}$ Our sample is unbalanced, and its structure can be observed in Table 6 in "Appendix". The number of observations ranges from a minimum of 148,000 firms in 1998 to a maximum of 331,000 firms in 2007. There is significant churning among firms during our sample period: only $7.2 \%$ of firms (18.3\% of total firm-year observations) have the full 10-year accounting information, and about $38 \%$ of firms ( $9.5 \%$ of firm-year observations) only exist for one or 2 years and then exit. ${ }^{3}$ Brandt et al. (2012) regard the active entry and exit of firms as the consequence of enterprise restructuring, which began in earnest in the mid-1990s.

Besides the standard income statement and balance sheet information, the NBS data contain a continuous measure of firms' ownership, which is based on the fraction of paid-in-capital contributed by the following six different types of investors: the state; foreign investors (excluding those from Hong Kong, Macao, and Taiwan); investors from Hong Kong, Macao, and Taiwan; ${ }^{4}$ collective investors; ${ }^{5}$ legal entities or corporation investors; ${ }^{6}$ and individual investors. We use this information to represent ownership, which is superior to the registration information of firms' ownership, as the latter does not reflect the dynamic nature of firm ownership evolution over the sample period.

Another feature of the NBS dataset is the inclusion of an index on firms' political affiliation. Political affiliation refers to the fact that firms are affiliated (have a lishu relationship) with the central, provincial, and local governments (Li 2004; Tan et al. 2007; Xia et al. 2009). A

\footnotetext{
2 We think it is important not to, a priori, drop what may seem to be outliers without direct evidence. In this paper, outliers are only dropped when experiencing problems in running regressions, by using the BACON procedure in STATA (Billor et al. 2000).

${ }^{3}$ We found a significant number of firms were allocated the wrong firm ID marker in the original data, which we corrected using company name, detailed location and 5-digit industry SIC codes. This had consequences for when firms entered and exited the dataset.

${ }^{4}$ Investors from Hong Kong, Macao, and Taiwan, and those from other parts of the world are entered separately because the former capture the so-called 'round-tripping' foreign direct investment, whereby domestic firms may register as foreign invested firms from nearby regions to take advantage of the benefits (such as tax and legal benefits) granted to foreign invested firms (Huang 2003).

5 Collective firms are generally owned collectively by communities in urban or rural areas. The latter are known as township and village enterprises (TVEs).

${ }^{6}$ Legal entities comprise industrial enterprises, construction and real estate development companies, transportation and power companies, security companies, trust and investment companies, foundations and funds, banks, technology and research institutions and so on.
} 
lishu relationship is associated with government support and subsidies. In particular, governments can grant firms affiliated with them benefits such as bank loans at better conditions, waivers of import tariffs, tax reductions and so on. On the other hand, firms with such political affiliation are more likely to engage in investment/production that does not aim to maximize firm value but to achieve objectives preferred by the government. We classify firms into three groups according to various degrees of political affiliation, i.e. high political affiliation (firms affiliated with central or provincial governments), medium political affiliation (firms affiliated with local governments such as city-, district-, county-, prefecture-, township- and villagelevel governments), and no political affiliation (those having no political affiliation). We believe that both the ownership and political affiliation information are important when examining firm productivity in the Chinese context, because such institutional factors have a significant impact on firms' decision making and behavior in China.

\subsection{Empirical methods for TFP estimation and approach used}

The objective of productivity measurement is to identify output differences that cannot be explained by input differences (Van Biesebroeck 2007). There are some advantages of estimating TFP using micro-level data. For instance, Del Gatto et al. (2011) argue that although aggregate analysis plays an important role in cross-country comparative analysis, firm-level analysis enables the investigation of TFP patterns at a deeper level controlling for issues like non-competitive markets, increasing returns, and heterogeneous firms.

Previous studies (of China and elsewhere) have used different approaches to estimating TFP using micro-level panel data (see Sect. 2 above for details). Van Beveren (2012) reviews various problems of estimating firm-level TFP, such as the endogeneity of input choices (or simultaneity bias), the omitted variable bias (if data on physical inputs and output and their corresponding firm-level prices are unavailable), the sample selection bias (as a result of no allowance of firm entry and exit), and the multiple-productfirm problem (which arises when production technology differs across products produced by single firm). To tackle these problems, he compares the performance of various estimators including fixed effects, GMM, and some semiparametric estimators like Olley and Pakes (1996) and Levinsohn and Petrin (2003), where investment and intermediate inputs are used to proxy for unobserved productivity, respectively. He argues that the preferred estimator depends on the extent to which the data satisfies the assumptions underlying the specific estimation algorithm.
Van Biesebroeck (2007) compares the sensitivity of five widely used productivity measures (index numbers, data envelopment analysis, stochastic frontiers, GMM, and semi-parametric estimation) using simulated data. Despite the fact that each method has its own strengths and weakness, the system GMM estimator is viewed as the most robust technique when measurement errors and technological heterogeneity are present.

Here, we calculate TFP using a Cobb-Douglas log-linear production function approach including fixed effects. The inclusion of fixed effects is necessary as empirical evidence using firm-level panel data consistently shows that firms are heterogeneous (productivity distributions are significantly 'spread' out with large 'tails' of firms with low TFP), but more importantly that the distribution is persistent-firms typically spend long periods in the same part of the distribution (see, for instance, Bartelsman and Dhrymes 1998; Haskel 2000; and Martin 2008). Such persistence suggests that firms have 'fixed' characteristics (associated with access to different path dependent (in)tangible resources, managerial and other capabilities) that change little through time, and thus need to be modeled. In the light of these considerations, we estimate the following model:

$y_{i t}=\alpha_{i}+\alpha_{E} e_{i t}+\alpha_{M} m_{i t}+\alpha_{K} k_{i t}+\alpha_{X} X_{i t}+\alpha_{T} t+\varepsilon_{i t}$

where endogenous $y, e, m$ and $k$ refer respectively to the logarithms of real gross output, employment, intermediate inputs, and the capital stock in firm $i$ at time $t$ $(i=1, \ldots, N ; \quad t=1, \ldots T) ;^{7}$ and $X_{i t}$ is a vector of observed (proxy) variables determining TFP (see Sect. 3.3, below). We include firm characteristics such as firm age, political affiliation, firm ownership, export behavior, whether the firm engaged in $R \& D$, financial variables, and geographic location into the vector $X_{i t}$ (Table 1 provides a list of the variables used). Lastly, $t$ is a time trend, measuring exogenous gains in TFP over time.

We first estimate Eq. (1) for different industries, and obtain the values of the elasticities of output with respect to inputs $\left(\alpha_{E}, \alpha_{M}\right.$, and $\left.\alpha_{K}\right)$. TFP can then be calculated as the level of output that is not attributable to factor inputs (employment, intermediate inputs and capital). ${ }^{8}$ In other

\footnotetext{
7 In theory, the production function should relate the flow of factor services to the flow of goods and services produced. In practice, however, we rarely have data on capital and labour utilization at the micro-level. This measurement error is included in $\varepsilon_{i t}$.

${ }^{8}$ It is known in the productivity literature that ideally one would use firm-specific price deflators when constructing TFP. Since such information is not available in our data, we use different industryspecific price deflators for inputs and outputs, which are obtained from various China statistical yearbooks. The deflator for investment is drawn directly from Brandt et al. (2012). This implies that our TFP measure is a revenue-based productivity measure (i.e., incorporates both differences in prices being charged by firms as well as the
} 
Table 1 Descriptive statistics for variables used in TFP estimation, China 1998-2007

\begin{tabular}{|c|c|c|c|c|c|c|c|}
\hline \multirow[t]{2}{*}{ Variables } & \multirow[t]{2}{*}{ Definition } & \multicolumn{2}{|c|}{$1998-2007$} & \multicolumn{2}{|l|}{1998} & \multicolumn{2}{|l|}{2007} \\
\hline & & Mean & $\mathrm{SD}$ & Mean & SD & Mean & SD \\
\hline In sales & In sales (billion RMB 2002 prices) & -4.054 & 1.475 & -4.587 & 1.633 & -3.608 & 1.300 \\
\hline $\begin{array}{l}\text { In intermediate } \\
\text { inputs }\end{array}$ & In intermediate inputs (billion RMB 2002 prices) & -4.404 & 1.478 & -4.824 & 1.627 & -4.115 & 1.349 \\
\hline In employment & ln employment & 4.781 & 1.159 & 5.053 & 1.244 & 4.639 & 1.097 \\
\hline ln capital & In real net tangible fixed assets (billion RMB 2002 prices) & -5.556 & 1.763 & -5.503 & 1.795 & -5.525 & 1.707 \\
\hline ln firm age & In firm age (based on year-of-birth) & 2.211 & 0.907 & 2.428 & 0.940 & 2.084 & 0.817 \\
\hline no_politics & No political affiliation & 0.524 & 0.499 & 0.157 & 0.363 & 0.760 & 0.427 \\
\hline med_politics & Medium political affiliation with local governments & 0.417 & 0.493 & 0.722 & 0.448 & 0.210 & 0.407 \\
\hline high_politics & High political affiliation with central or provincial governments & 0.060 & 0.237 & 0.121 & 0.327 & 0.030 & 0.172 \\
\hline p_capstate & proportion of capital owned by the State & 0.135 & 0.329 & 0.325 & 0.452 & 0.036 & 0.178 \\
\hline p_capcoll & proportion of capital owned by collective firms & 0.125 & 0.315 & 0.290 & 0.423 & 0.046 & 0.199 \\
\hline p_capcorporate & proportion of capital owned by corporations/legal entities & 0.212 & 1.190 & 0.123 & 0.291 & 0.270 & 2.898 \\
\hline p_capindividual & proportion of capital owned by individuals & 0.384 & 1.219 & 0.144 & 0.319 & 0.494 & 2.908 \\
\hline p_caphkmactai & proportion of capital owned by HK/Macao/Taiwan & 0.075 & 0.248 & 0.066 & 0.224 & 0.075 & 0.252 \\
\hline p_capforeign & proportion of capital owned by foreigners & 0.070 & 0.236 & 0.053 & 0.197 & 0.079 & 0.255 \\
\hline Exporter & A dummy variable for firms that export & 0.256 & 0.436 & 0.216 & 0.411 & 0.237 & 0.426 \\
\hline In Herfindahl & ln Herfindahl index of industrial concentration (by 2-digit SIC) & -6.329 & 1.005 & -6.075 & 1.024 & -6.603 & 0.992 \\
\hline $\begin{array}{l}\ln \\
\text { diversification }\end{array}$ & $\begin{array}{l}\text { In proportion of 3-digit industries (maximum 226) located in (208) city } \\
\text { areas in which firm is located-Jacobian spillovers }\end{array}$ & -0.647 & 0.373 & -0.477 & 0.409 & -0.645 & 0.324 \\
\hline $\begin{array}{l}\text { ln } \\
\text { agglomeration }\end{array}$ & $\begin{array}{l}\ln \% \text { of industry output (2-digit SIC) located in each province in which } \\
\text { firm is located-MAR-spillovers }\end{array}$ & 1.747 & 1.160 & 1.599 & 1.124 & 1.850 & 1.122 \\
\hline R\&D dummy & Dummy variable $=1$ if firm undertook any spending on $R \& D$ & 0.110 & 0.313 & 0.097 & 0.295 & 0.106 & 0.308 \\
\hline $\ln$ fixed costs & ln selling \& distribution costs as $\%$ of sales & 1.084 & 0.895 & 1.203 & 0.945 & 0.982 & 0.810 \\
\hline Neg_liquid & $\begin{array}{l}\text { Dummy variable }=1 \text { if ratio of (current assets-current liabilities) to } \\
\text { total assets } \leq 0\end{array}$ & 0.417 & 0.493 & 0.496 & 0.500 & 0.377 & 0.485 \\
\hline In liquidity & $\ln [1+$ ratio of (current assets-current liabilities) to total assets $]$ & 0.124 & 0.155 & 0.099 & 0.143 & 0.137 & 0.160 \\
\hline City200 & Dummy $=1$ for firm located in top 200 cities based on population size & 0.783 & 0.412 & 0.270 & 0.444 & 0.875 & 0.331 \\
\hline $\mathrm{N}$ & No. of observations & $\begin{array}{l}2138.8 \\
\text { thousa }\end{array}$ & & 140.9 th & busand & 329.7 the & ousand \\
\hline
\end{tabular}

words, productivity is due to efficiency levels and technical progress. Thus, such a measure of TFP can be expressed as: ${ }^{9}$

Footnote 8 continued

underlying physical productivity of the firm). As discussed by Foster et al. (2008), we are therefore capturing both technical efficiency and price-cost markups.

${ }^{9}$ Using more familiar notation, TFP here is defined as $A_{\mathrm{it}}$ in the standard Cobb-Douglas production function:

$Y_{i t}=A_{i t} E_{i t}^{\alpha_{E}} M_{i t}^{\alpha_{M}} K_{i t}^{\alpha_{\kappa}}$

and thus:

$A_{i t}=Y_{i t} /\left(E_{i t}^{\alpha_{\bar{E}}} M_{i t}^{\alpha_{M}} K_{i t}^{\alpha_{K}}\right)$

Note, $\ln$ TFP is defined here by replacing $\ln A_{\mathrm{it}}$ with the last term in Eq. (2). TFP is this determined by (1) the variables captured in $X_{\text {it }}$ (which account for plants being 'on' or 'inside' the current 'bestpractice' technology); (2) the time trend (which shifts the 'best-

$$
\begin{aligned}
\ln \widehat{T F P}_{i t} & =y_{i t}-\hat{\alpha}_{E} e_{i t}-\hat{\alpha}_{M} m_{i t}-\hat{\alpha}_{K} k_{i t} \\
& =\hat{\alpha}_{l}+\widehat{\alpha_{X}} X_{i t}+\widehat{\alpha}_{T} t+\hat{\varepsilon}_{i t}
\end{aligned}
$$

Note, Eq. (2) is not a proper TFP index, because the measure of input growth $\left(\hat{\alpha}_{E} e_{i t}-\hat{\alpha}_{M} m_{i t}-\hat{\alpha}_{K} k_{i t}\right.$, equivalent to the change in the denominator in Eq. 4) does not satisfy axiom X5 (proportionality) in O'Donnell (2015), except in the case of constant returns-to-scale. The solution is to restore proportionality by using a special case of the Färe and Primont (1995) input index. The measure of TFP becomes:

$$
\ln \widehat{T F P}_{i t}^{F P}=y_{i t}-\frac{1}{\hat{\alpha}_{E}+\hat{\alpha}_{M}+\hat{\alpha}_{K}}\left(\hat{\alpha}_{E} e_{i t}+\hat{\alpha}_{M} m_{i t}+\hat{\alpha}_{K} k_{i t}\right)
$$

Footnote 9 continued practice' frontier generally outwards); and (3) plant-level fixed effects and idiosyncratic shocks captured by the error term. 
An alternative approach, popular in the literature, is to estimate (1) without including $X_{i t}$ on the right-hand-side of the equation, and then use (2) to obtain TFP, where $X_{i t}$ is now part of the random error term $\left(\hat{\varepsilon}_{i t}\right)$. Typically, $\ln \widehat{T F P}_{i t}$ obtained from Eq. (2) is then regressed on $X_{i t}$ to measure the determinants of TFP as part of a two-stage approach. Clearly, we would expect estimates of the elasticities of output (and thus $\ln \widehat{T F P}_{i t}$ ) from this two-stage approach to be biased because of an omitted variable(s) problem.

A large class of models has been used to estimate the parameters of Eq. (1), using micro-level panel data. Here we concentrate on the two most popular in recent work. The first includes the Olley and Pakes (1996) and Levinsohn and Petrin (2003) approaches, which account for both endogeneity of inputs in the production function and selection bias due to firm entry and exit (which is likely to be correlated with productivity), by using two-stage procedures where unobserved TFP is 'proxied' by another state variable(s) such as investment or intermediate inputs. In essence, Olley and Pakes (OP) replace Eq. (1) with:

$y_{i t}=\beta_{0}+\beta_{E} e_{i t}+\beta_{M} m_{i t}+\beta_{K} k_{i t}+h\left(i_{i t}, k_{i t}\right)+\varepsilon_{i t}$

where TFP is proxied by $h(\cdot)$-which itself is approximated by a higher-order polynomial in $i_{i t}$ and $k_{i t}$-and $i_{i t}$ is investment. Levinsohn and Petrin (LP) replace $h(\cdot)$ with $h\left(m_{i t}, k_{i t}\right)$. Both approaches do not allow for fixed effects and make some strong assumptions when compared to the systems GMM approach (as discussed in Ackerberg et al. 2006).

We therefore use the other popular approach to microlevel estimation: that is, Eq. (1)—in dynamic form with additional lagged values of output and factor inputs-is estimated using the two-step XTABOND2 system GMM approach (Arellano and Bond 1991) implemented in STATA (this also involves correcting for any potential finite sample bias using Windmeijer's 2005, approach). Thus Eq. (1) is estimated both in first-differences and in levels, allowing for fixed effects and tackling endogeneity of the right-hand-side variables (including the lagged dependent variable) and selection bias by using lagged values of the endogenous variables as instruments in the first differences equation, and first-differences of the same variables as instruments in the levels equation (Blundell and Bond 1998). ${ }^{10}$ In this study, gross output, intermediate

\footnotetext{
10 The validity of the instruments (i.e. the fact that they are correlated with endogenous regressors but are not correlated with the production function error term - and hence productivity) can be tested. It is wellknown by those that use the approach that the parameter estimates obtained (and the ability to pass diagnostic tests) is sensitive to the instrument set used (see Roodman 2009, for practical guidance on applying the system-GMM approach). So for example, we use Roodman's (2009) 'collapse' procedure in all our estimations using XTABOND2 in STATA, such that only the instruments applicable to
}

inputs, labour, and capital are treated as endogenous, as well as political affiliation, capital ownership, exporting, and R\&D. Lastly, according to Arellano and Bond (1991), the presence of second-order autocorrelation implies that the estimates are inconsistent. Panel tests for autocorrelation are used to establish whether second-order correlation is an issue.

\subsection{Justification for variables used as determinants of TFP (i.e., $X_{i t}$ )}

As stated in the introduction, inclusion of $X_{i t}$ is important as omission of these variables would produce biased estimates of the production function, and thus biased estimates of TFP. Our choice of $X_{i t}$ is in part determined by the information available to us in the NBS dataset, and by previous work that uses similar variables. A detailed justification for the majority of the variables used is available in Harris and Moffat (2015). Here we provide just an overview of key arguments.

Firms' age is included to measure whether younger firms produce with greater efficiency and better technology than older plants (a vintage capital effect); or if productivity increases as the firm ages through learning-by-doing (e.g. Jovanovic and Nyarko 1996).

Our inclusion of the lishu relationship was discussed above, and also encompasses the likely impact of State ownership of capital. Other forms of ownership are less likely to be subject to the impact of political influence, while foreign-owned firms are expected to possess characteristics (e.g. specialised knowledge about production and better management or marketing capabilities) that give them a cost advantage over domestic firms (Hymer 1976). These firms are therefore expected to be more efficient. Conversely, cultural differences between the owners of the firm and the workforce may act to lower levels of TFP in foreign owned plants, especially in the immediate period after the establishment of new 'greenfield' operations, or the acquisition of an existing enterprise. Dunning (1988) suggests a lack of understanding of management and labour attitudes as one such disadvantage possessed by foreign owned firms in developed countries. There are likely to be even larger and more embedded issues for foreign-owned firms operating in China. In the long(er)run, this problem should be overcome as the owners of the indigenous firm become more familiar with domestic working practices/institutional environment.

Footnote 10 continued

each variable - not the full instrument set covering all variables-are used. Too many instruments have been shown to often result in a Hansen $p$ value at or very close to 1 . 
Exporting is expected to be associated with the need of such firms to achieve productivity gains prior to exporting, while there can also be 'learning-by-exporting' effects post-entry (Greenaway and Kneller 2007, provide a survey of this literature).

A measure of the concentration of output across firms, and therefore of market power, is usually included to take account of competition effects. Under the assumption that the elasticity of demand does not vary too greatly across firms in an industry, this is a valid measure of competition within an industry (see, for example, Cabral 2000). Intuitively, one would expect that greater competition will pressure firms into adopting new technologies and operating more efficiently (e.g. Nickell 1996; Meyer and Vickers 1997). However, it can also be argued-following Schumpeter (1943) and more recent endogenous growth theory models - that the level of competition may be inversely related to productivity if monopoly rents are required for management to invest in $R \& D$ which in turn leads to innovation and improvements in TFP (Dixit and Stiglitz 1977; Aghion et al. 2001; Aghion and Howitt 1992, 1999; Romer 1990; Grossman and Helpman 1991). It has also been shown that, under some conditions, increased competition can lower the expected income of managers and therefore their effort (Hermalin 1992). This reduced effort may be reflected in reductions in firm efficiency levels.

Agglomeration externalities are usually distinguished in the literature according to whether they are an intra- or inter-industry phenomenon. Intra-industry externalities are termed MAR (Marshall 1890; Arrow 1962; Romer 1986) or localisation externalities, while inter-industry externalities are termed Jacobian (Jacobs 1970, 1986) or urbanisation externalities. The mechanisms that give rise to agglomeration externalities can support both localisation and urbanisation externalities. We also include a dummy that takes on a value of 1 for those firms located in one of the top 200 cities (based on population size in year $t$ ), as an additional proxy for potential negative spillovers (i.e. 'congestion' costs) in large Chinese cities. For instance, firms may learn from other firms in the same industry and from firms in another industry.

When estimating models of TFP, internal and external knowledge creation is usually represented by both endogenous technical progress due to undertaking $R \& D$ in the firm, and by exogenous gains over time, as well as its obsolescence (as represented by the age of the plant-see above). R\&D is expected to have an impact on TFP through two channels. Most obviously, performing R\&D may generate process innovations that allow existing products to be produced with greater efficiency (through lower costs). It may also generate product innovations which will improve TFP if the new products are produced with greater efficiency or by using better technology than existing products (i.e. an outward shift of the firm's production possibility frontier). The second channel is through the development of absorptive capacity (see Cohen and Levinthal 1989, and especially Zahra and George 2002, for a detailed discussion of the concept). Absorptive capacity permits the identification, assimilation and exploitation of innovations made by other firms and R\&D actors, such as universities and research institutes, and is therefore also expected to lead to improvements in TFP. The notion of absorptive capacity is based on the observation that some knowledge is tacit and is difficult to acquire unless the firm is directly involved in R\&D in the area. These two channels through which R\&D may affect TFP reflect the two 'faces' of R\&D (Griffith et al. 2004).

We use selling and distribution expenses as a percentage of sales as a proxy for managerial efficiency (i.e. marketing efficiency_-see Lee and Rugman 2012), and/or corporate governance problems (as a proxy for discretionary spending and self-aggrandisement-or organizational slack, i.e. the risk of corporate governance problems). Furthermore Chen and Guariglia (2013) argue that the availability of liquid assets enhances the firms' capacity to obtain cash at short notice, since liquid assets can be mobilized to raise cash for financing productive projects (it is also required to ensure that the firm has sufficient working capital to finance day-to-day operations). This suggests that liquidity has a fundamental role for financing those activities, which are likely to determine a shift in the efficiency frontier, or best practice technology, which thus impacts on TFP.

\section{Results of TFP estimation}

\subsection{Descriptive statistics}

Table 1 presents the summary statistics of variables used in Eq. (1). It is interesting to see that the majority of firms in the sample $(52 \%)$ have no political affiliations with any level of government, and the ratio of unaffiliated firms dramatically increases from $15.7 \%$ in 1998 to $76 \%$ in 2007. In 1998, more than $72 \%$ of firms had medium-level political affiliation with local governments, but the ratio quickly declined to $21 \%$ in 2007 . The diminishing role of government in the Chinese industrial sector can be viewed as an outcome of China's marketization reform starting from the late 1970 s.

In terms of ownership, our sample is dominated by private firms, i.e. $38.4 \%$ of firm-year observations are owned by individual investors, and $21.1 \%$, by corporation/ legal entities investors over the period of 1998-2007. There is an interesting pattern of the evolution of ownership over the ten-year period. The proportion of state ownership in 
our sample declines dramatically, from $32.5 \%$ in 1998 to $3.6 \%$ in 2007. A similar pattern holds for collective firms, whose share declines from 29 to $4.6 \%$. In contrast, the share of individual investors climbs from 14.4 to $49.4 \%$, and the corresponding figures for corporation/legal entities investors are $12.3 \%$ in 1998 and $27 \%$ in 2007. The share of foreign investors and investors from Hong Kong, Macaw and Taiwan remains roughly stable at between 6 and $8 \%$ respectively. Privatization of small state-owned enterprises (SOEs) and collective firms became significant after 1998 (Haggard and Huang 2008). Our dataset reflects the restructuring process involved in the shrinkage of the state and collective sectors and the expansion of the private sector.

Lastly, our data is dominated by non-exporters, i.e. $74.7 \%$ of firms do not export over the sample period. The ratio remains stable between 1998 and 2007, but the volume of export sales increases. Finally, most firms in our sample $(89 \%)$ do not engage in $R \& D$. There was also evidence of a significant trend in urbanization in China, i.e. $27 \%$ firms located in the top 200 cities in 1998 whereas the corresponding figure rises to 87.5 in 2007.

\subsection{Econometric results}

We begin the discussion of our results with reference to the (only other comparable) study by Brandt et al. (2012) - see Sect. 2-noting their use of the Olley and Pakes (1996) and Ackerberg et al. (2006) approach. Thus unlike the present study, they do not allow for fixed effects and also do not include the vector $X_{i t}$ in Eq. (2), and thus they measure TFP essentially as the time trend plus (assumed) random shocks to technology-i.e., overall, they make no attempt to explain the determinants of TFP.

The detailed results from estimating Eq. (1) for 26 twodigit industries/industry groups are presented in Tables $2 .^{11,12}$ Firstly as the diagnostics show, the estimates

\footnotetext{
11 Some industries are combined for the TFP estimation. For instance, special equipment (SIC 36) is combined with ordinary machinery (SIC 35); pressing ferrous (SIC 32) and pressing of nonferrous (SIC 33) are combined with metal products (SIC 34); artwork and other manufacturing (SIC 42) is combined with other manufacturing (SIC 43); electrical machinery and equipment (SIC 39) is combined with communications equipment computers and other electronic equipment (SIC 40); and other mining (SIC 80) is combined with other mining (SIC 10). Some industries are not reported in this version of the paper. For example, timber logging (SIC12) has too few observations and is omitted entirely. The results for agricultural and sideline food processing (SIC 13), beverages (SIC 15), and electrical machinery and equipment (SIC 39) combined with communications equipment (SIC 40) are also not reported due to the failure to pass the Hansen test in the GMM estimation.

12 Some industries (SIC10, 23, 34, 45 and 46) initially encountered problems in passing the Hansen test; some (SIC14, 17, 23, $26+28$, 31 and 44$)$ had problems with the $\operatorname{AR}(2)$ test. Yet, these problems
}

obtained are economically sensible, and pass various tests of the validity of the instruments used and tests for autocorrelation. All 26 models pass the Hansen test for overidentification at the $5 \%$ level or better, suggesting the validity of the instrument set used. ${ }^{13}$ With regard to tests for autocorrelation, all models show evidence of significant negative first-order serial correlation in differenced residuals, and none show evidence of second-order serial correlation in the differenced residuals (based on a $5 \%$ significance level), suggesting the overall consistency of our estimates.

The elasticities of output with respect to intermediate input, labor and capital display significant heterogeneity among various industries, but they are all positive and significant. ${ }^{14}$ It is interesting to note that our results based on the system GMM estimator show increasing returns-toscale (RTS) for most industries (20 out of 26 industries) with an average sum of the output elasticities equal to 1.12. ${ }^{15}$ By contrast, when using the approach of Levinsohn and Petrin (2003), we obtain decreasing returns to scale for 11 industries, with an average sum of the output elasticities equal to 0.51 (which is very low and, in our view, implausible). Besides, when the Levinsohn and Petrin (2003) method is adopted, we also find that the estimated elasticities with respect to output are generally much lower for capital and labor, but higher for intermediate inputs. ${ }^{16}$ We believe our results obtained using system GMM (e.g. increasing returns) are more plausible for the rapidly growing Chinese economy (e.g., see the model and results presented in Song et al. 2011).

The time trend is included to account for (Hicks-neutral) technical change and to capture the impact on TFP of exogenous improvements in technology that are common to all firms. The coefficient on the time trend is positive and significant for all industries with two exceptions (insignificant for petroleum processing and for textiles). The time trend is more important in some industries such as

Footnote 12 continued were resolved after removing outliers (about $15 \%$ of the observations) using the BACON procedure in STATA (see Billor et al, 2000).

${ }^{13}$ Note that 7 industries only passed the Hansen test at the $5 \%$ level; the rest at the desired $10 \%$ level (or better). For these 7 industries, we therefore accept (caveat emptor) there may be some unknown level of bias in the estimates attached to the endogenous variables. However, we would argue that the general conclusions arrived at about the determinants of TFP are not seriously affected-for example, we get similar overall results including and excluding these seven industries.

14 The only exception is the food production industry (SIC 14), where the coefficient of employment is positive but insignificant.

15 All other industries display constant returns to scale, in that the sum of the output elasticities are not significantly different to 1 .

16 To save space, the results based on the Levinsohn and Petrin (2003) method are not reported but are available at https://dl. dropboxusercontent.com/u/72592486/LevP_by_SIC.xlsx. 
Table 2 Long-run two-step system-GMM production function (26 industries, China)

\begin{tabular}{|c|c|c|c|c|c|c|}
\hline Dependent variable: $\ln$ sales & $\begin{array}{l}\text { Other mining } \\
(\mathrm{SIC} 10+80)\end{array}$ & $\begin{array}{l}\text { Food production } \\
\text { (SIC14) }\end{array}$ & $\begin{array}{l}\text { Tobacco } \\
\text { (SIC16) }\end{array}$ & $\begin{array}{l}\text { Textile } \\
\text { (SIC17) }\end{array}$ & $\begin{array}{l}\text { Apparel and footwear } \\
\text { (SIC18) }\end{array}$ & $\begin{array}{l}\text { Leather } \\
\text { (SIC19) }\end{array}$ \\
\hline \multicolumn{7}{|l|}{ Panel A } \\
\hline In intermediate inputs & $\begin{array}{l}0.308 * * * \\
(0.074)\end{array}$ & $\begin{array}{l}0.366 * * \\
(0.157)\end{array}$ & $\begin{array}{l}0.386 * * * \\
(0.082)\end{array}$ & $\begin{array}{l}0.769 * * * \\
(0.015)\end{array}$ & $\begin{array}{l}0.653 * * * \\
(0.049)\end{array}$ & $\begin{array}{l}0.763 * * * \\
(0.058)\end{array}$ \\
\hline ln employment & $\begin{array}{l}0.505 * * * \\
(0.064)\end{array}$ & $\begin{array}{l}0.311 * \\
(0.174)\end{array}$ & $\begin{array}{l}0.613 * * \\
(0.287)\end{array}$ & $\begin{array}{l}0.267 * * * \\
(0.029)\end{array}$ & $\begin{array}{l}0.294 * * * \\
(0.041)\end{array}$ & $\begin{array}{l}0.095 * \\
(0.053)\end{array}$ \\
\hline ln capital & $\begin{array}{l}0.225 * * * \\
(0.065)\end{array}$ & $\begin{array}{l}0.357 * \\
(0.196)\end{array}$ & $\begin{array}{l}0.387 * * \\
(0.161)\end{array}$ & $\begin{array}{l}0.045 * * \\
(0.018)\end{array}$ & $\begin{array}{l}0.085 * * \\
(0.038)\end{array}$ & $\begin{array}{l}0.143 * \\
(0.073)\end{array}$ \\
\hline Time trend & $\begin{array}{l}0.067 * * * \\
(0.005)\end{array}$ & $\begin{array}{l}0.040 * * * \\
(0.007)\end{array}$ & $\begin{array}{l}0.042 * * * \\
(0.015)\end{array}$ & $\begin{array}{l}-0.002 \\
(0.001)\end{array}$ & $\begin{array}{l}0.045^{* * *} \\
(0.002)\end{array}$ & $\begin{array}{l}0.024 * * * \\
(0.005)\end{array}$ \\
\hline ln firm age & $\begin{array}{l}-0.014 \\
(0.011)\end{array}$ & $\begin{array}{l}-0.011 \\
(0.013)\end{array}$ & $\begin{array}{l}-0.045 \\
(0.082)\end{array}$ & $\begin{array}{l}-0.024 * * * \\
(0.004)\end{array}$ & $\begin{array}{l}-0.031 * * * \\
(0.008)\end{array}$ & $\begin{array}{l}-0.034 * \\
(0.019)\end{array}$ \\
\hline No political affiliation & $\begin{array}{l}0.047 * * * \\
(0.011)\end{array}$ & $\begin{array}{l}0.038 * * * \\
(0.011)\end{array}$ & $\begin{array}{l}0.184 * \\
(0.097)\end{array}$ & $\begin{array}{l}0.022 * * * \\
(0.002)\end{array}$ & $\begin{array}{l}0.016 * * * \\
(0.005)\end{array}$ & $\begin{array}{l}-0.002 \\
(0.006)\end{array}$ \\
\hline High political affiliation & $\begin{array}{l}-0.233^{* * *} \\
(0.050)\end{array}$ & $\begin{array}{l}0.017 \\
(0.029)\end{array}$ & $\begin{array}{l}-0.072 \\
(0.159)\end{array}$ & $\begin{array}{l}-0.034 * * * \\
(0.011)\end{array}$ & $\begin{array}{l}0.023 \\
(0.025)\end{array}$ & $\begin{array}{l}-0.105 \\
(0.065)\end{array}$ \\
\hline p_capstate & $\begin{array}{l}-0.361^{* * *} \\
(0.086)\end{array}$ & $\begin{array}{l}-0.119 * * * \\
(0.040)\end{array}$ & $\begin{array}{l}0.429 \\
(0.389)\end{array}$ & $\begin{array}{l}0.007 \\
(0.009)\end{array}$ & $\begin{array}{l}-0.097 * * * \\
(0.027)\end{array}$ & $\begin{array}{l}-0.282 * * * \\
(0.081)\end{array}$ \\
\hline p_capcoll & $\begin{array}{l}0.131 * \\
(0.074)\end{array}$ & $\begin{array}{l}0.066 \\
(0.047)\end{array}$ & $\begin{array}{l}0.561 \\
(0.399)\end{array}$ & $\begin{array}{l}0.051 * * * \\
(0.008)\end{array}$ & $\begin{array}{l}0.024 * \\
(0.014)\end{array}$ & $\begin{array}{l}0.004 \\
(0.037)\end{array}$ \\
\hline p_capcorporate & $\begin{array}{l}0.002 \\
(0.058)\end{array}$ & $\begin{array}{l}0.035 \\
(0.036)\end{array}$ & $\begin{array}{l}0.391 \\
(0.396)\end{array}$ & $\begin{array}{l}0.044 * * * \\
(0.007)\end{array}$ & $\begin{array}{l}0.036 * * * \\
(0.013)\end{array}$ & $\begin{array}{l}0.002 \\
(0.034)\end{array}$ \\
\hline p_capindividual & $\begin{array}{l}0.014 \\
(0.062)\end{array}$ & $\begin{array}{l}0.052 \\
(0.045)\end{array}$ & $\begin{array}{l}0.814^{*} \\
(0.436)\end{array}$ & $\begin{array}{l}0.048 * * * \\
(0.007)\end{array}$ & $\begin{array}{l}0.044 * * * \\
(0.016)\end{array}$ & $\begin{array}{l}0.020 \\
(0.041)\end{array}$ \\
\hline p_capforeign & $\begin{array}{l}-0.056 \\
(0.062)\end{array}$ & $\begin{array}{l}-0.031 \\
(0.035)\end{array}$ & $\begin{array}{l}0.015 \\
(0.528)\end{array}$ & $\begin{array}{l}0.008 \\
(0.005)\end{array}$ & $\begin{array}{l}0.012 * \\
(0.006)\end{array}$ & $\begin{array}{l}0.008 \\
(0.011)\end{array}$ \\
\hline Exporter & $\begin{array}{l}0.268 \\
(0.243)\end{array}$ & $\begin{array}{l}0.003 \\
(0.015)\end{array}$ & $\begin{array}{l}0.310 * \\
(0.163)\end{array}$ & $\begin{array}{l}0.016^{* * *} \\
(0.003)\end{array}$ & $\begin{array}{l}0.018 * * \\
(0.009)\end{array}$ & $\begin{array}{l}-0.053 \\
(0.127)\end{array}$ \\
\hline$R \& D$ dummy & $\begin{array}{l}0.036 \\
(0.116)\end{array}$ & $\begin{array}{l}0.015 \\
(0.019)\end{array}$ & $\begin{array}{l}-0.242 \\
(0.168)\end{array}$ & $\begin{array}{l}0.016 * * * \\
(0.006)\end{array}$ & $\begin{array}{l}0.027 * * \\
(0.011)\end{array}$ & $\begin{array}{l}0.142 \\
(0.204)\end{array}$ \\
\hline ln agglomeration & $\begin{array}{l}0.157 * * * \\
(0.020)\end{array}$ & $\begin{array}{l}0.060 * * * \\
(0.020)\end{array}$ & $\begin{array}{l}0.140 * * \\
(0.062)\end{array}$ & $\begin{array}{l}0.039 * * * \\
(0.007)\end{array}$ & $\begin{array}{l}0.057 * * * \\
(0.015)\end{array}$ & $\begin{array}{l}0.051 * * * \\
(0.018)\end{array}$ \\
\hline ln Herfindahl & $\begin{array}{l}-0.157 * * * \\
(0.018)\end{array}$ & $\begin{array}{l}-0.147 * * * \\
(0.028)\end{array}$ & $\begin{array}{l}0.110 \\
(0.082)\end{array}$ & $\begin{array}{l}0.167 * * * \\
(0.008)\end{array}$ & $\begin{array}{l}0.062 * * * \\
(0.022)\end{array}$ & $\begin{array}{l}-0.051 * * \\
(0.021)\end{array}$ \\
\hline In diversification & $\begin{array}{l}0.058 * * * \\
(0.017)\end{array}$ & $\begin{array}{l}0.083 * * * \\
(0.016)\end{array}$ & $\begin{array}{l}0.068 \\
(0.052)\end{array}$ & $\begin{array}{l}0.087 * * * \\
(0.006)\end{array}$ & $\begin{array}{l}0.198 * * * \\
(0.015)\end{array}$ & $\begin{array}{l}0.108 * * * \\
(0.020)\end{array}$ \\
\hline In fixed costs & $\begin{array}{l}-0.053^{* * *} \\
(0.007)\end{array}$ & $\begin{array}{l}-0.067 * * * \\
(0.018)\end{array}$ & $\begin{array}{l}-0.057 * * \\
(0.026)\end{array}$ & $\begin{array}{l}-0.011^{* * *} \\
(0.002)\end{array}$ & $\begin{array}{l}-0.000 \\
(0.005)\end{array}$ & $\begin{array}{l}-0.038 * * * \\
(0.012)\end{array}$ \\
\hline Neg_liquid & $\begin{array}{l}-0.038^{* * *} \\
(0.008)\end{array}$ & $\begin{array}{l}-0.049 * * * \\
(0.012)\end{array}$ & $\begin{array}{l}-0.035 \\
(0.053)\end{array}$ & $\begin{array}{l}-0.016^{* * *} \\
(0.003)\end{array}$ & $\begin{array}{l}-0.050 \text { *** } \\
(0.009)\end{array}$ & $\begin{array}{l}-0.041 * * * \\
(0.014)\end{array}$ \\
\hline In liquidity & $\begin{array}{l}0.617 * * * \\
(0.111)\end{array}$ & $\begin{array}{l}0.451 * * \\
(0.187)\end{array}$ & $\begin{array}{l}0.865 * * * \\
(0.220)\end{array}$ & $\begin{array}{l}0.115 * * * \\
(0.017)\end{array}$ & $\begin{array}{l}0.220 * * * \\
(0.047)\end{array}$ & $\begin{array}{l}0.236 * * \\
(0.092)\end{array}$ \\
\hline CIty 200 & $\begin{array}{l}0.005 \\
(0.015)\end{array}$ & $\begin{array}{l}-0.028^{*} \\
(0.016)\end{array}$ & $\begin{array}{l}-0.054 \\
(0.054)\end{array}$ & $\begin{array}{l}-0.019 * * * \\
(0.004)\end{array}$ & $\begin{array}{l}-0.068 * * * \\
(0.006)\end{array}$ & $\begin{array}{l}-0.084 * * * \\
(0.011)\end{array}$ \\
\hline Constant & $\begin{array}{l}-4.557 * * * \\
(0.679)\end{array}$ & $\begin{array}{l}-3.007 * * \\
(1.462)\end{array}$ & $\begin{array}{l}-2.435 \\
(2.129)\end{array}$ & $\begin{array}{l}-0.419^{* *} \\
(0.198)\end{array}$ & $\begin{array}{l}-1.862 * * * \\
(0.462)\end{array}$ & $\begin{array}{l}-0.352 \\
(0.566)\end{array}$ \\
\hline Province dummies & Yes & Yes & Yes & Yes & Yes & Yes \\
\hline Observations & 37,858 & 25,785 & 2244 & 94,516 & 94,106 & 46,267 \\
\hline Number of firms & 13,060 & 9455 & 483 & 33,951 & 27,447 & 13,223 \\
\hline
\end{tabular}


Table 2 continued

\begin{tabular}{|c|c|c|c|c|c|c|c|}
\hline \multirow{2}{*}{$\begin{array}{l}\text { Dependent variable: } \ln \text { sales } \\
\text { AR(1) z-statistic }\end{array}$} & \multirow{2}{*}{$\begin{array}{l}\begin{array}{l}\text { Other mining } \\
(\mathrm{SIC} 10+80)\end{array} \\
-10.482\end{array}$} & $\begin{array}{l}\text { Food production } \\
\text { (SIC14) }\end{array}$ & \multirow{2}{*}{$\begin{array}{l}\begin{array}{l}\text { Tobacco } \\
(\text { SIC16) }\end{array} \\
-4.743\end{array}$} & \multirow{2}{*}{$\begin{array}{l}\begin{array}{l}\text { Textile } \\
(\text { SIC17) }\end{array} \\
-25.88\end{array}$} & \multicolumn{2}{|c|}{$\begin{array}{l}\text { Apparel and footwear } \\
\text { (SIC18) }\end{array}$} & \multirow{2}{*}{$\begin{array}{l}\begin{array}{l}\text { Leather } \\
\text { (SIC19) }\end{array} \\
-11.620\end{array}$} \\
\hline & & -4.951 & & & -15.221 & & \\
\hline $\operatorname{AR}(1)$ z-statistic $(p)$ & 0 & 0.000 & 0 & 0 & 0 & & 0 \\
\hline $\operatorname{AR}(2) z$-statistic & -1.362 & -1.585 & 0.449 & -1.830 & -1.392 & & -1.735 \\
\hline $\operatorname{AR}(2)$ z-statistic $(p)$ & 0.173 & 0.113 & 0.653 & 0.067 & 0.164 & & 0.083 \\
\hline Hansen test & 7.585 & 4.648 & 10.63 & 10.000 & 7.298 & & 12.97 \\
\hline Hansen test $(p)$ & 0.270 & 0.325 & 0.474 & 0.125 & 0.199 & & 0.073 \\
\hline Returns-to-scale $(-1)$ & 0.037 & $0.035^{*}$ & $0.386^{* *}$ & $0.081 * * *$ & $0.032 *$ & & $0.109 * * *$ \\
\hline RTS (-1) Levinson-Petrin & $0.047 * * *$ & $0.081 * * *$ & $0.332 * * *$ & $-0.189 * * *$ & -0.002 & & $-0.191 * * *$ \\
\hline Dependent variable: $\ln$ sales & $\begin{array}{l}\text { Timber } \\
\text { (SIC20) }\end{array}$ & $\begin{array}{l}\text { Furniture } \\
\text { (SIC21) }\end{array}$ & $\begin{array}{l}\text { Paper-making } \\
\text { (SIC22) }\end{array}$ & $\begin{array}{l}\text { Printing } \\
\text { (SIC23) }\end{array}$ & $\begin{array}{l}\text { Cultural } \\
\text { (SIC24) }\end{array}$ & $\begin{array}{l}\text { Petrol } \\
\text { (SIC2 }\end{array}$ & $\begin{array}{l}\text { n processing } \\
-70)\end{array}$ \\
\hline \multicolumn{8}{|l|}{ Panel B } \\
\hline ln intermediate inputs & $\begin{array}{l}0.493 * * * \\
(0.118)\end{array}$ & $\begin{array}{l}0.494 * * * \\
(0.068)\end{array}$ & $\begin{array}{l}0.843 * * * \\
(0.032)\end{array}$ & $\begin{array}{l}0.627 * * * \\
(0.046)\end{array}$ & $\begin{array}{l}0.754 * * * \\
(0.051)\end{array}$ & $\begin{array}{l}0.265^{*} \\
(0.145)\end{array}$ & \\
\hline ln employment & $\begin{array}{l}0.483 * * * \\
(0.114)\end{array}$ & $\begin{array}{l}0.446 * * * \\
(0.078)\end{array}$ & $\begin{array}{l}0.166 * * * \\
(0.045)\end{array}$ & $\begin{array}{l}0.227 * * \\
(0.108)\end{array}$ & $\begin{array}{l}0.239 * * * \\
(0.067)\end{array}$ & $\begin{array}{l}0.743^{*} \\
(0.145)\end{array}$ & \\
\hline In capital & $\begin{array}{l}0.130 * \\
(0.076)\end{array}$ & $\begin{array}{l}0.169 * * * \\
(0.046)\end{array}$ & $\begin{array}{l}0.040 * * * \\
(0.009)\end{array}$ & $\begin{array}{l}0.186 * * * \\
(0.048)\end{array}$ & $\begin{array}{l}0.059 * \\
(0.031)\end{array}$ & $\begin{array}{l}0.245^{* *} \\
(0.100)\end{array}$ & \\
\hline Time trend & $\begin{array}{l}0.054 * * * \\
(0.009)\end{array}$ & $\begin{array}{l}0.030 * * * \\
(0.004)\end{array}$ & $\begin{array}{l}0.034 * * * \\
(0.004)\end{array}$ & $\begin{array}{l}0.049 * * * \\
(0.006)\end{array}$ & $\begin{array}{l}0.074 * * * \\
(0.005)\end{array}$ & $\begin{array}{l}-0.005 \\
(0.008)\end{array}$ & \\
\hline ln firm age & $\begin{array}{l}-0.022 * * \\
(0.011)\end{array}$ & $\begin{array}{l}-0.058^{* * *} \\
(0.013)\end{array}$ & $\begin{array}{l}-0.018^{* *} \\
(0.008)\end{array}$ & $\begin{array}{l}-0.105^{* * *} \\
(0.028)\end{array}$ & $\begin{array}{l}-0.005 \\
(0.013)\end{array}$ & $\begin{array}{l}-0.080 \\
(0.027)\end{array}$ & \\
\hline No political affiliation & $\begin{array}{l}0.025^{*} \\
(0.013)\end{array}$ & $\begin{array}{l}0.018 \\
(0.012)\end{array}$ & $\begin{array}{l}0.014 * * * \\
(0.005)\end{array}$ & $\begin{array}{l}0.036 * * * \\
(0.008)\end{array}$ & $\begin{array}{l}0.004 \\
(0.008)\end{array}$ & $\begin{array}{l}0.053^{* *} \\
(0.020)\end{array}$ & \\
\hline High political affiliation & $\begin{array}{l}-0.223 * * * \\
(0.085)\end{array}$ & $\begin{array}{l}-0.093^{*} \\
(0.050)\end{array}$ & $\begin{array}{l}-0.000 \\
(0.019)\end{array}$ & $\begin{array}{l}0.047 * * \\
(0.018)\end{array}$ & $\begin{array}{l}-0.008 \\
(0.035)\end{array}$ & $\begin{array}{l}-0.034 \\
(0.070)\end{array}$ & \\
\hline p_capstate & $\begin{array}{l}-0.160 * \\
(0.085)\end{array}$ & $\begin{array}{l}-0.219 * * * \\
(0.065)\end{array}$ & $\begin{array}{l}-0.114 * * \\
(0.050)\end{array}$ & $\begin{array}{l}0.103 \\
(0.063)\end{array}$ & $\begin{array}{l}-0.164 * * \\
(0.078)\end{array}$ & $\begin{array}{l}-0.214 \\
(0.087)\end{array}$ & \\
\hline p_capcoll & $\begin{array}{l}0.181 * * * \\
(0.050)\end{array}$ & $\begin{array}{l}0.202 * * * \\
(0.047)\end{array}$ & $\begin{array}{l}-0.042 \\
(0.047)\end{array}$ & $\begin{array}{l}0.294 * * * \\
(0.066)\end{array}$ & $\begin{array}{l}-0.054 \\
(0.047)\end{array}$ & $\begin{array}{l}-0.031 \\
(0.089)\end{array}$ & \\
\hline p_capcorporate & $\begin{array}{l}0.126 * * * \\
(0.035)\end{array}$ & $\begin{array}{l}0.223 * * * \\
(0.041)\end{array}$ & $\begin{array}{l}-0.048 \\
(0.045)\end{array}$ & $\begin{array}{l}0.231 * * * \\
(0.061)\end{array}$ & $\begin{array}{l}-0.041 \\
(0.039)\end{array}$ & $\begin{array}{l}-0.018 \\
(0.077)\end{array}$ & \\
\hline p_capindividual & $\begin{array}{l}0.124 * * * \\
(0.040)\end{array}$ & $\begin{array}{l}0.201 * * * \\
(0.043)\end{array}$ & $\begin{array}{l}-0.045 \\
(0.046)\end{array}$ & $\begin{array}{l}0.243 * * * \\
(0.064)\end{array}$ & $\begin{array}{l}-0.030 \\
(0.041)\end{array}$ & $\begin{array}{l}0.011 \\
(0.082)\end{array}$ & \\
\hline p_capforeign & $\begin{array}{l}0.050 * * \\
(0.025)\end{array}$ & $\begin{array}{l}0.059 * * * \\
(0.017)\end{array}$ & $\begin{array}{l}0.016 \\
(0.015)\end{array}$ & $\begin{array}{l}0.047 * \\
(0.027)\end{array}$ & $\begin{array}{l}0.023 * \\
(0.013)\end{array}$ & $\begin{array}{l}0.185^{*}: \\
(0.086)\end{array}$ & \\
\hline Exporter & $\begin{array}{l}0.091 \\
(0.057)\end{array}$ & $\begin{array}{l}0.074 \\
(0.064)\end{array}$ & $\begin{array}{l}-0.169 \\
(0.127)\end{array}$ & $\begin{array}{l}0.377 * * * \\
(0.145)\end{array}$ & $\begin{array}{l}-0.261 \\
(0.160)\end{array}$ & $\begin{array}{l}0.563 * * \\
(0.185)\end{array}$ & \\
\hline$R \& D$ dummy & $\begin{array}{l}0.592 * \\
(0.348)\end{array}$ & $\begin{array}{l}-0.008 \\
(0.018)\end{array}$ & $\begin{array}{l}0.168 * * \\
(0.072)\end{array}$ & $\begin{array}{l}0.127 * * * \\
(0.036)\end{array}$ & $\begin{array}{l}0.023 \\
(0.015)\end{array}$ & $\begin{array}{l}0.005 \\
(0.046)\end{array}$ & \\
\hline ln agglomeration & $\begin{array}{l}0.133 * * * \\
(0.034)\end{array}$ & $\begin{array}{l}0.119 * * * \\
(0.024)\end{array}$ & $\begin{array}{l}0.076 * * * \\
(0.014)\end{array}$ & $\begin{array}{l}0.080 * * * \\
(0.020)\end{array}$ & $\begin{array}{l}-0.005 \\
(0.021)\end{array}$ & $\begin{array}{l}0.106^{* *} \\
(0.032)\end{array}$ & \\
\hline ln Herfindahl & $\begin{array}{l}0.036 \\
(0.025)\end{array}$ & $\begin{array}{l}-0.174 * * * \\
(0.036)\end{array}$ & $\begin{array}{l}-0.141^{* * *} \\
(0.012)\end{array}$ & $\begin{array}{l}0.085 * * * \\
(0.024)\end{array}$ & $\begin{array}{l}0.347 * * * \\
(0.059)\end{array}$ & $\begin{array}{l}-0.323 \\
(0.078)\end{array}$ & \\
\hline ln diversification & $\begin{array}{l}0.207 * * * \\
(0.034)\end{array}$ & $\begin{array}{l}0.223 * * * \\
(0.030)\end{array}$ & $\begin{array}{l}0.200 * * * \\
(0.014)\end{array}$ & $\begin{array}{l}0.255^{* * * *} \\
(0.017)\end{array}$ & $\begin{array}{l}0.127 * * * \\
(0.024)\end{array}$ & $\begin{array}{l}0.147^{*}: \\
(0.054)\end{array}$ & \\
\hline
\end{tabular}


Table 2 continued

\begin{tabular}{|c|c|c|c|c|c|c|}
\hline Dependent variable: $\ln$ sales & $\begin{array}{l}\text { Timber } \\
\text { (SIC20) }\end{array}$ & $\begin{array}{l}\text { Furniture } \\
\text { (SIC21) }\end{array}$ & $\begin{array}{l}\text { Paper-making } \\
\text { (SIC22) }\end{array}$ & $\begin{array}{l}\text { Printing } \\
\text { (SIC23) }\end{array}$ & $\begin{array}{l}\text { Cultural } \\
\text { (SIC24) }\end{array}$ & $\begin{array}{l}\text { Petroleum processing } \\
(\text { SIC25 }+70)\end{array}$ \\
\hline ln fixed costs & $\begin{array}{l}-0.058 * * * \\
(0.013)\end{array}$ & $\begin{array}{l}-0.061 * * * \\
(0.011)\end{array}$ & $\begin{array}{l}-0.019 * * * \\
(0.005)\end{array}$ & $\begin{array}{l}-0.035^{* * *} \\
(0.006)\end{array}$ & $\begin{array}{l}-0.010 \\
(0.006)\end{array}$ & $\begin{array}{l}-0.045^{* * *} \\
(0.013)\end{array}$ \\
\hline Neg_liquid & $\begin{array}{l}-0.042 * * * \\
(0.013)\end{array}$ & $\begin{array}{l}-0.052^{* * *} \\
(0.011)\end{array}$ & $\begin{array}{l}-0.023 * * * \\
(0.005)\end{array}$ & $\begin{array}{l}-0.064 * * * \\
(0.008)\end{array}$ & $\begin{array}{l}-0.026^{* * *} \\
(0.009)\end{array}$ & $\begin{array}{l}-0.078^{* * *} \\
(0.023)\end{array}$ \\
\hline In liquidity & $\begin{array}{l}0.348 * * \\
(0.136)\end{array}$ & $\begin{array}{l}0.408 * * * \\
(0.075)\end{array}$ & $\begin{array}{l}0.195 * * * \\
(0.027)\end{array}$ & $\begin{array}{l}0.483 * * * \\
(0.084)\end{array}$ & $\begin{array}{l}0.197 * * * \\
(0.056)\end{array}$ & $\begin{array}{l}0.740 * * * \\
(0.179)\end{array}$ \\
\hline CIty 200 & $\begin{array}{l}-0.034 * \\
(0.020)\end{array}$ & $\begin{array}{l}-0.073^{* * *} \\
(0.014)\end{array}$ & $\begin{array}{l}-0.096^{* * * *} \\
(0.008)\end{array}$ & $\begin{array}{l}-0.139 * * * \\
(0.015)\end{array}$ & $\begin{array}{l}0.002 \\
(0.013)\end{array}$ & $\begin{array}{l}0.019 \\
(0.029)\end{array}$ \\
\hline Constant & $\begin{array}{l}-3.128 * * * \\
(0.841)\end{array}$ & $\begin{array}{l}-4.049 * * * \\
(0.779)\end{array}$ & $\begin{array}{l}-1.707 * * * \\
(0.297)\end{array}$ & $\begin{array}{l}-0.558 \\
(0.848)\end{array}$ & $\begin{array}{l}0.107 \\
(0.743)\end{array}$ & $\begin{array}{l}-5.308^{* * *} \\
(1.121)\end{array}$ \\
\hline Province dummies & Yes & Yes & Yes & Yes & Yes & Yes \\
\hline Observations & 38,762 & 22,234 & 57,792 & 39,362 & 24,427 & 12,378 \\
\hline Number of firms & 12,942 & 6980 & 15,111 & 10,437 & 6963 & 4129 \\
\hline $\operatorname{AR}(1) z$-statistic & -10.553 & -5.504 & -13.63 & -17.64 & -9.141 & -5.802 \\
\hline $\operatorname{AR}(1)$ z-statistic $(p)$ & 0 & 0 & 0 & 0 & 0 & 0 \\
\hline $\operatorname{AR}(2) z$-statistic & -1.765 & -1.385 & -1.574 & -1.309 & -1.081 & -1.379 \\
\hline $\operatorname{AR}(2)$ z-statistic $(p)$ & 0.078 & 0.166 & 0.115 & 0.191 & 0.280 & 0.168 \\
\hline Hansen test & 12.84 & 13.83 & 6.341 & 21.76 & 12.47 & 11.79 \\
\hline Hansen test $(p)$ & 0.117 & 0.129 & 0.386 & 0.084 & 0.188 & 0.108 \\
\hline Returns-to-scale $(-1)$ & $0.106^{*}$ & $0.109 * * *$ & $0.050 * *$ & 0.040 & $0.053^{*}$ & $0.253 * * *$ \\
\hline RTS $(-1)$ Levinson-Petrin & -0.002 & $-0.191 * * *$ & $-0.210 * * *$ & $0.030 * * *$ & -0.012 & $-0.012 *$ \\
\hline Dependent variable: $\ln$ sales & $\begin{array}{l}\text { Chemical } \\
(\text { SIC26 + 28) }\end{array}$ & $\begin{array}{l}\text { Medical } \\
\text { (SIC27) }\end{array}$ & $\begin{array}{l}\text { Rubber } \\
\text { (SIC29) }\end{array}$ & $\begin{array}{l}\text { Plastic } \\
\text { (SIC30) }\end{array}$ & $\begin{array}{l}\text { Nonmetal products } \\
\text { (SIC31) }\end{array}$ & $\begin{array}{l}\text { Metal products } \\
\quad(\text { SIC } 32+33+34)\end{array}$ \\
\hline \multicolumn{7}{|l|}{ Panel C } \\
\hline In intermediate inputs & $\begin{array}{l}0.604 * * * \\
(0.029)\end{array}$ & $\begin{array}{l}0.550 * * * \\
(0.040)\end{array}$ & $\begin{array}{l}0.555 * * * \\
(0.112)\end{array}$ & $\begin{array}{l}0.860 * * * \\
(0.048)\end{array}$ & $\begin{array}{l}0.215 * * \\
(0.109)\end{array}$ & $\begin{array}{l}0.441 * * \\
(0.035)\end{array}$ \\
\hline ln employment & $\begin{array}{l}0.398 * * * \\
(0.067)\end{array}$ & $\begin{array}{l}0.768 * * * \\
(0.102)\end{array}$ & $\begin{array}{l}0.249 * \\
(0.146)\end{array}$ & $\begin{array}{l}0.110 * * \\
(0.048)\end{array}$ & $\begin{array}{l}0.421 * \\
(0.252)\end{array}$ & $\begin{array}{l}0.344 * * * \\
(0.045)\end{array}$ \\
\hline ln capital & $\begin{array}{l}0.055 * * \\
(0.023)\end{array}$ & $\begin{array}{l}0.065^{* *} \\
(0.027)\end{array}$ & $\begin{array}{l}0.153 * \\
(0.080)\end{array}$ & $\begin{array}{l}0.066 * * * \\
(0.024)\end{array}$ & $\begin{array}{l}0.556 * * * \\
(0.126)\end{array}$ & $\begin{array}{l}0.462 * * * \\
(0.059)\end{array}$ \\
\hline Time trend & $\begin{array}{l}0.034 * * * \\
(0.002)\end{array}$ & $\begin{array}{l}0.047 * * * \\
(0.005)\end{array}$ & $\begin{array}{l}0.051 * * * \\
(0.013)\end{array}$ & $\begin{array}{l}0.023 * * * \\
(0.004)\end{array}$ & $\begin{array}{l}0.077 * * * \\
(0.015)\end{array}$ & $\begin{array}{l}0.08 * * * \\
(0.004)\end{array}$ \\
\hline ln firm age & $\begin{array}{l}-0.112^{* * * *} \\
(0.010)\end{array}$ & $\begin{array}{l}-0.162 * * * \\
(0.027)\end{array}$ & $\begin{array}{l}-0.052 * \\
(0.026)\end{array}$ & $\begin{array}{l}-0.012 \\
(0.012)\end{array}$ & $\begin{array}{l}-0.065^{* * *} \\
(0.027)\end{array}$ & $\begin{array}{l}-0.147 * * * \\
(0.016)\end{array}$ \\
\hline No political affiliation & $\begin{array}{l}0.049 * * * \\
(0.006)\end{array}$ & $\begin{array}{l}0.071 * * * \\
(0.013)\end{array}$ & $\begin{array}{l}0.030 * * * \\
(0.011)\end{array}$ & $\begin{array}{l}0.002 \\
(0.005)\end{array}$ & $\begin{array}{l}0.045^{* * *} \\
(0.009)\end{array}$ & $\begin{array}{l}0.045 * * * \\
(0.007)\end{array}$ \\
\hline High political affiliation & $\begin{array}{l}-0.049 * * \\
(0.019)\end{array}$ & $\begin{array}{l}-0.015 \\
(0.018)\end{array}$ & $\begin{array}{l}-0.005 \\
(0.053)\end{array}$ & $\begin{array}{l}-0.017 \\
(0.02)\end{array}$ & $\begin{array}{l}-0.030 \\
(0.026)\end{array}$ & $\begin{array}{l}-0.317 * * * \\
(0.041)\end{array}$ \\
\hline p_capstate & $\begin{array}{l}-0.162^{* * *} \\
(0.027)\end{array}$ & $\begin{array}{l}-0.219 * * * \\
(0.037)\end{array}$ & $\begin{array}{l}-0.150 * \\
(0.083)\end{array}$ & $\begin{array}{l}-0.045 \\
(0.03)\end{array}$ & $\begin{array}{l}-0.140 \\
(0.092)\end{array}$ & $\begin{array}{l}-0.017 \\
(0.041)\end{array}$ \\
\hline p_capcoll & $\begin{array}{l}-0.027 \\
(0.022)\end{array}$ & $\begin{array}{l}-0.028 \\
(0.033)\end{array}$ & $\begin{array}{l}0.121 \\
(0.099)\end{array}$ & $\begin{array}{l}0.028 \\
(0.035)\end{array}$ & $\begin{array}{l}0.088 \\
(0.091)\end{array}$ & $\begin{array}{l}0.439 * * * \\
(0.051)\end{array}$ \\
\hline p_capcorporate & $\begin{array}{l}-0.039 * \\
(0.022)\end{array}$ & $\begin{array}{l}-0.077 * * * \\
(0.029)\end{array}$ & $\begin{array}{l}0.099 \\
(0.089)\end{array}$ & $\begin{array}{l}0.026 \\
(0.031)\end{array}$ & $\begin{array}{l}0.088 \\
(0.075)\end{array}$ & $\begin{array}{l}0.353 * * * \\
(0.042)\end{array}$ \\
\hline p_capindividual & $\begin{array}{l}-0.019 \\
(0.021)\end{array}$ & $\begin{array}{l}-0.023 \\
(0.029)\end{array}$ & $\begin{array}{l}0.100 \\
(0.095)\end{array}$ & $\begin{array}{l}0.022 \\
(0.034)\end{array}$ & $\begin{array}{l}0.102 \\
(0.084)\end{array}$ & $\begin{array}{l}0.425 * * * \\
(0.049)\end{array}$ \\
\hline
\end{tabular}


Table 2 continued

\begin{tabular}{|c|c|c|c|c|c|c|}
\hline Dependent variable: $\ln$ sales & $\begin{array}{l}\text { Chemical } \\
(\text { SIC26 + 28) }\end{array}$ & $\begin{array}{l}\text { Medical } \\
\text { (SIC27) }\end{array}$ & $\begin{array}{l}\text { Rubber } \\
\text { (SIC29) }\end{array}$ & $\begin{array}{l}\text { Plastic } \\
\text { (SIC30) }\end{array}$ & $\begin{array}{l}\text { Nonmetal products } \\
\text { (SIC31) }\end{array}$ & $\begin{array}{l}\text { Metal products } \\
(\mathrm{SIC} 32+33+34)\end{array}$ \\
\hline p_capforeign & $\begin{array}{l}0.031 * * \\
(0.015)\end{array}$ & $\begin{array}{l}0.079 * * \\
(0.032)\end{array}$ & $\begin{array}{l}0.025 \\
(0.028)\end{array}$ & $\begin{array}{l}0.023 * * * \\
(0.008)\end{array}$ & $\begin{array}{l}0.020 \\
(0.050)\end{array}$ & $\begin{array}{l}0.025 \\
(0.023)\end{array}$ \\
\hline Exporter & $\begin{array}{l}0.038 \\
(0.055)\end{array}$ & $\begin{array}{l}-0.079 \\
(0.110)\end{array}$ & $\begin{array}{l}0.149 \\
(0.173)\end{array}$ & $\begin{array}{l}-0.035 \\
(0.055)\end{array}$ & $\begin{array}{l}0.076 \\
(0.195)\end{array}$ & $\begin{array}{l}-0.052 \\
(0.087)\end{array}$ \\
\hline$R \& D$ dummy & $\begin{array}{l}0.085 \\
(0.087)\end{array}$ & $\begin{array}{l}0.222 * \\
(0.129)\end{array}$ & $\begin{array}{l}0.261 \\
(0.196)\end{array}$ & $\begin{array}{l}0.135^{*} \\
(0.08)\end{array}$ & $\begin{array}{l}-0.082 \\
(0.078)\end{array}$ & $\begin{array}{l}0.001 \\
(0.013)\end{array}$ \\
\hline In agglomeration & $\begin{array}{l}0.024 * * \\
(0.010)\end{array}$ & $\begin{array}{l}0.155 * * * \\
(0.024)\end{array}$ & $\begin{array}{l}-0.011 \\
(0.025)\end{array}$ & $\begin{array}{l}0.034 * \\
(0.018)\end{array}$ & $\begin{array}{l}0.128 * * * \\
(0.023)\end{array}$ & $\begin{array}{l}0.003 \\
(0.021)\end{array}$ \\
\hline ln Herfindahl & $\begin{array}{l}-0.083^{* * *} \\
(0.010)\end{array}$ & $\begin{array}{l}-0.234 * * * \\
(0.029)\end{array}$ & $\begin{array}{l}-0.201 * * * \\
(0.068)\end{array}$ & $\begin{array}{l}-0.034^{* *} \\
(0.014)\end{array}$ & $\begin{array}{l}-0.147 * * * \\
(0.037)\end{array}$ & $\begin{array}{l}0.117 * * * \\
(0.017)\end{array}$ \\
\hline ln diversification & $\begin{array}{l}0.144 * * * \\
(0.013)\end{array}$ & $\begin{array}{l}0.165 * * * \\
(0.018)\end{array}$ & $\begin{array}{l}0.198 * * * \\
(0.030)\end{array}$ & $\begin{array}{l}0.135 * * * \\
(0.015)\end{array}$ & $\begin{array}{l}0.216 * * * \\
(0.024)\end{array}$ & $\begin{array}{l}0.239 * * * \\
(0.014)\end{array}$ \\
\hline ln fixed costs & $\begin{array}{l}-0.063 * * * \\
(0.005)\end{array}$ & $\begin{array}{l}-0.129 * * * \\
(0.015)\end{array}$ & $\begin{array}{l}-0.046^{* * *} \\
(0.012)\end{array}$ & $\begin{array}{l}-0.018 * * * \\
(0.007)\end{array}$ & $\begin{array}{l}-0.017 * * * \\
(0.006)\end{array}$ & $\begin{array}{l}-0.092 * * * \\
(0.008)\end{array}$ \\
\hline Neg_liquid & $\begin{array}{l}-0.032 * * * \\
(0.005)\end{array}$ & $\begin{array}{l}-0.046^{* * *} \\
(0.010)\end{array}$ & $\begin{array}{l}-0.053 * * * \\
(0.018)\end{array}$ & $\begin{array}{l}-0.017^{* *} \\
(0.007)\end{array}$ & $\begin{array}{l}-0.067 * * * \\
(0.009)\end{array}$ & $\begin{array}{l}-0.107 * * * \\
(0.012)\end{array}$ \\
\hline In liquidity & $\begin{array}{l}0.243 * * * \\
(0.029)\end{array}$ & $\begin{array}{l}0.495 * * * \\
(0.055)\end{array}$ & $\begin{array}{l}0.337 * * * \\
(0.096)\end{array}$ & $\begin{array}{l}0.262 * * * \\
(0.039)\end{array}$ & $\begin{array}{l}0.880 * * * \\
(0.130)\end{array}$ & $\begin{array}{l}0.944 * * * \\
(0.085)\end{array}$ \\
\hline CIty 200 & $\begin{array}{l}-0.027 * * * \\
(0.008)\end{array}$ & $\begin{array}{l}-0.094 * * * \\
(0.015)\end{array}$ & $\begin{array}{l}-0.114 * * * \\
(0.018)\end{array}$ & $\begin{array}{l}-0.107 * * * \\
(0.011)\end{array}$ & $\begin{array}{l}-0.044 * * \\
(0.020)\end{array}$ & $\begin{array}{l}-0.09^{* * * *} \\
(0.01)\end{array}$ \\
\hline Constant & $\begin{array}{l}-5.944 * * * \\
(0.429)\end{array}$ & $\begin{array}{l}-5.495^{* * * *} \\
(0.468)\end{array}$ & $\begin{array}{l}-3.005 * * * \\
(1.042)\end{array}$ & $\begin{array}{l}-0.636^{*} \\
(-0.353)\end{array}$ & $\begin{array}{l}-3.741 * \\
(2.007)\end{array}$ & $\begin{array}{l}-0.933 * \\
(0.043)\end{array}$ \\
\hline Province dummies & Yes & Yes & Yes & Yes & Yes & Yes \\
\hline Observations & 84,284 & 33,367 & 22,894 & 55,225 & 103,975 & 93,059 \\
\hline Number of firms & 29,381 & 8952 & 6611 & 18,323 & 34,625 & 32,965 \\
\hline $\operatorname{AR}(1) z$-statistic & -16.53 & -12.442 & -5.941 & -8.279 & -5.620 & -11.343 \\
\hline $\operatorname{AR}(1)$ z-statistic $(p)$ & 0 & 0 & 0 & 0 & 0 & 0 \\
\hline $\operatorname{AR}(2) z$-statistic & -0.945 & -1.147 & -1.431 & -1.315 & -1.100 & -1.876 \\
\hline $\operatorname{AR}(2)$ z-statistic $(p)$ & 0.345 & 0.251 & 0.152 & 0.188 & 0.270 & 0.061 \\
\hline Hansen test & 8.188 & 13.92 & 14.18 & 10.33 & 9.590 & 15.98 \\
\hline Hansen test $(p)$ & 0.515 & 0.084 & 0.116 & 0.412 & 0.143 & 0.100 \\
\hline Returns-to-scale $(-1)$ & $0.057 * *$ & $0.383 * * *$ & -0.043 & $0.035^{*}$ & $0.191 * *$ & $0.247 * * *$ \\
\hline RTS $(-1)$ Levinson-Petrin & 0.009 & $-0.023^{* *}$ & 0.013 & -0.002 & $-0.259 * * *$ & 0.027 \\
\hline Dependent variable: $\ln$ sales & $\begin{array}{l}\text { Machinery \& } \\
\text { Equipment } \\
(\text { SIC35 + 36) }\end{array}$ & \multicolumn{2}{|c|}{$\begin{array}{l}\text { Transport } \\
\text { equipment } \\
\text { (SIC37) }\end{array}$} & $\begin{array}{l}\text { Measuring } \\
\text { instrument } \\
\text { (SIC41) }\end{array}$ & $\begin{array}{l}\text { Other } \\
\text { manufacturing } \\
(\text { SIC42 }+43)\end{array}$ & $\begin{array}{l}\text { Electronic } \\
\text { power } \\
\text { (SIC44) }\end{array}$ \\
\hline \multicolumn{7}{|l|}{ Panel D } \\
\hline In intermediate inputs & $\begin{array}{l}0.626 * * * \\
(0.035)\end{array}$ & \multicolumn{2}{|c|}{$0.640 * * *$} & $\begin{array}{l}0.562 * * * \\
(0.142)\end{array}$ & $\begin{array}{l}0.649 * * \\
(0.045)^{*}\end{array}$ & $\begin{array}{l}0.278 * * * \\
(0.044)\end{array}$ \\
\hline In employment & $\begin{array}{l}0.450 * * * \\
(0.065)\end{array}$ & \multicolumn{2}{|c|}{$0.383^{* * *}$} & $\begin{array}{l}0.460 * * \\
(0.197)\end{array}$ & $\begin{array}{l}0.162 * * * \\
(0.053)\end{array}$ & $\begin{array}{l}0.602 * * * \\
(0.154)\end{array}$ \\
\hline ln capital & $\begin{array}{l}0.104 * * \\
(0.046)\end{array}$ & \multicolumn{2}{|c|}{$0.094^{*}$} & $\begin{array}{l}0.202 * \\
(0.117)\end{array}$ & $\begin{array}{l}0.135 * * * \\
(0.030)\end{array}$ & $\begin{array}{l}0.196^{*} \\
(0.053)\end{array}$ \\
\hline Time trend & $\begin{array}{l}0.078 * * * \\
(0.006)\end{array}$ & \multicolumn{2}{|c|}{$(0.007)$} & $\begin{array}{l}0.072 * * * \\
(0.008)\end{array}$ & $\begin{array}{l}0.024 * * * \\
(0.005)\end{array}$ & $\begin{array}{l}0.032 * * * \\
(0.010)\end{array}$ \\
\hline ln firm age & $\begin{array}{l}-0.109 * * * \\
(0.011)\end{array}$ & \multicolumn{2}{|c|}{$-0.076^{* * *}$} & $\begin{array}{l}-0.186^{* *} \\
(0.078)\end{array}$ & $\begin{array}{l}-0.073 * * * \\
(0.016)\end{array}$ & $\begin{array}{l}-0.064 \\
(0.039)\end{array}$ \\
\hline
\end{tabular}


Table 2 continued

\begin{tabular}{|c|c|c|c|c|c|}
\hline Dependent variable: $\ln$ sales & $\begin{array}{l}\text { Machinery \& } \\
\text { Equipment } \\
(\text { SIC35 + 36) }\end{array}$ & $\begin{array}{l}\text { Transport } \\
\text { equipment } \\
\text { (SIC37) }\end{array}$ & $\begin{array}{l}\text { Measuring } \\
\text { instrument } \\
\text { (SIC41) }\end{array}$ & $\begin{array}{l}\text { Other } \\
\text { manufacturing } \\
(\mathrm{SIC} 42+43)\end{array}$ & $\begin{array}{l}\text { Electronic } \\
\text { power } \\
\text { (SIC44) }\end{array}$ \\
\hline No political affiliation & $\begin{array}{l}0.031 * * * \\
(0.004)\end{array}$ & $\begin{array}{l}0.012 * * \\
(0.005)\end{array}$ & $\begin{array}{l}0.040 * * \\
(0.018)\end{array}$ & $\begin{array}{l}-0.015^{* * *} \\
(0.006)\end{array}$ & $\begin{array}{l}0.095 * * * \\
(0.028)\end{array}$ \\
\hline High political affiliation & $\begin{array}{l}-0.063^{* * *} \\
(0.016)\end{array}$ & $\begin{array}{l}-0.030 \\
(0.028)\end{array}$ & $\begin{array}{l}-0.046 \\
(0.042)\end{array}$ & $\begin{array}{l}0.034 \\
(0.026)\end{array}$ & $\begin{array}{l}0.028 \\
(0.042)\end{array}$ \\
\hline p_capstate & $\begin{array}{l}-0.208 * * * \\
(0.032)\end{array}$ & $\begin{array}{l}-0.049 \\
(0.047)\end{array}$ & $\begin{array}{l}-0.333 * \\
(0.193)\end{array}$ & $\begin{array}{l}-0.050 \\
(0.062)\end{array}$ & $\begin{array}{l}-0.157 * \\
(0.094)\end{array}$ \\
\hline p_capcoll & $\begin{array}{l}0.116^{* * * *} \\
(0.034)\end{array}$ & $\begin{array}{l}0.059 \\
(0.047)\end{array}$ & $\begin{array}{l}-0.001 \\
(0.152)\end{array}$ & $\begin{array}{l}0.170 * * * \\
(0.049)\end{array}$ & $\begin{array}{l}-0.049 \\
(0.075)\end{array}$ \\
\hline p_capcorporate & $\begin{array}{l}0.075 * * * \\
(0.026)\end{array}$ & $\begin{array}{l}0.065 \\
(0.041)\end{array}$ & $\begin{array}{l}-0.040 \\
(0.144)\end{array}$ & $\begin{array}{l}0.164 * * * \\
(0.042)\end{array}$ & $\begin{array}{l}-0.070 \\
(0.066)\end{array}$ \\
\hline p_capindividual & $\begin{array}{l}0.098 * * * \\
(0.029)\end{array}$ & $\begin{array}{l}0.067 \\
(0.044)\end{array}$ & $\begin{array}{l}0.010 \\
(0.156)\end{array}$ & $\begin{array}{l}0.166^{* * * *} \\
(0.042)\end{array}$ & $\begin{array}{l}-0.093 \\
(0.075)\end{array}$ \\
\hline p_capforeign & $\begin{array}{l}0.084 * * * \\
(0.016)\end{array}$ & $\begin{array}{l}0.037 * \\
(0.020)\end{array}$ & $\begin{array}{l}0.096 * * \\
(0.042)\end{array}$ & $\begin{array}{l}0.045 * * * \\
(0.014)\end{array}$ & $\begin{array}{l}-0.024 \\
(0.038)\end{array}$ \\
\hline Exporter & $\begin{array}{l}0.039 \\
(0.052)\end{array}$ & $\begin{array}{l}0.116^{*} \\
(0.069)\end{array}$ & $\begin{array}{l}-0.622 \\
(0.428)\end{array}$ & $\begin{array}{l}0.361 * * \\
(0.180)\end{array}$ & $\begin{array}{l}0.551 * * \\
(0.270)\end{array}$ \\
\hline$R \& D$ dummy & $\begin{array}{l}0.000 \\
(0.051)\end{array}$ & $\begin{array}{l}-0.308^{*} \\
(0.177)\end{array}$ & $\begin{array}{l}0.076 \\
(0.242)\end{array}$ & $\begin{array}{l}0.009 \\
(0.012)\end{array}$ & $\begin{array}{l}0.087 * * * \\
(0.025)\end{array}$ \\
\hline ln agglomeration & $\begin{array}{l}-0.016 \\
(0.014)\end{array}$ & $\begin{array}{l}-0.003 \\
(0.011)\end{array}$ & $\begin{array}{l}-0.061^{* *} \\
(0.028)\end{array}$ & $\begin{array}{l}-0.007 \\
(0.016)\end{array}$ & $\begin{array}{l}0.051 * * * \\
(0.016)\end{array}$ \\
\hline In Herfindahl & $\begin{array}{l}-0.054 * * * \\
(0.015)\end{array}$ & $\begin{array}{l}-0.080^{* * * *} \\
(0.021)\end{array}$ & $\begin{array}{l}0.061 * * * \\
(0.021)\end{array}$ & $\begin{array}{l}0.062 * * * \\
(0.015)\end{array}$ & $\begin{array}{l}-0.040 \\
(0.033)\end{array}$ \\
\hline ln diversification & $\begin{array}{l}0.241 * * * \\
(0.010)\end{array}$ & $\begin{array}{l}0.166 * * * \\
(0.017)\end{array}$ & $\begin{array}{l}0.181 * * * \\
(0.041)\end{array}$ & $\begin{array}{l}0.223 * * * \\
(0.022)\end{array}$ & $\begin{array}{l}0.009 \\
(0.015)\end{array}$ \\
\hline ln fixed costs & $\begin{array}{l}-0.057 * * * \\
(0.006)\end{array}$ & $\begin{array}{l}-0.033^{* * * *} \\
(0.009)\end{array}$ & $\begin{array}{l}-0.069 * * * \\
(0.026)\end{array}$ & $\begin{array}{l}-0.034 * * * \\
(0.006)\end{array}$ & $\begin{array}{l}-0.012^{* *} \\
(0.006)\end{array}$ \\
\hline Neg_liquid & $\begin{array}{l}-0.052 * * * \\
(0.006)\end{array}$ & $\begin{array}{l}-0.043^{* * *} \\
(0.008)\end{array}$ & $\begin{array}{l}-0.117 * * * \\
(0.029)\end{array}$ & $\begin{array}{l}-0.072 * * * \\
(0.010)\end{array}$ & $\begin{array}{l}-0.050^{* * *} \\
(0.013)\end{array}$ \\
\hline In liquidity & $\begin{array}{l}0.437 * * * \\
(0.053)\end{array}$ & $\begin{array}{l}0.301 * * * \\
(0.053)\end{array}$ & $\begin{array}{l}0.613 * * \\
(0.250)\end{array}$ & $\begin{array}{l}0.351 * * * \\
(0.055)\end{array}$ & $\begin{array}{l}0.214 \\
(0.160)\end{array}$ \\
\hline CIty 200 & $\begin{array}{l}-0.119 * * * \\
(0.009)\end{array}$ & $\begin{array}{l}-0.084 * * * \\
(0.012)\end{array}$ & $\begin{array}{l}-0.057 * * \\
(0.024)\end{array}$ & $\begin{array}{l}-0.072 * * * \\
(0.008)\end{array}$ & $\begin{array}{l}-0.006 \\
(0.015)\end{array}$ \\
\hline Constant & $\begin{array}{l}-3.431 * * * \\
(0.569)\end{array}$ & $\begin{array}{l}-2.785^{* * * *} \\
(0.798)\end{array}$ & $\begin{array}{l}-2.631 * \\
(1.407)\end{array}$ & $\begin{array}{l}-0.854 * * \\
(0.427)\end{array}$ & $\begin{array}{l}-2.135^{* *} \\
(0.892)\end{array}$ \\
\hline Province dummies & Yes & Yes & Yes & Yes & Yes \\
\hline Observations & 276,450 & 72,401 & 42,265 & 60,473 & 36,793 \\
\hline Number of firms & 84,449 & 22,159 & 14,731 & 19,250 & 7838 \\
\hline $\operatorname{AR}(1) z$-statistic & -29.244 & -10.372 & -10.01 & -15.561 & -7.273 \\
\hline $\operatorname{AR}(1)$ z-statistic $(p)$ & 0 & 0 & 0 & 0 & 0 \\
\hline $\operatorname{AR}(2) z$-statistic & -1.363 & -1.587 & -1.392 & -1.329 & 1.327 \\
\hline $\operatorname{AR}(2)$ z-statistic $(p)$ & 0.173 & 0.112 & 0.164 & 0.184 & 0.185 \\
\hline Hansen test & 18.33 & 13.40 & 6.520 & 6.529 & 12.81 \\
\hline Hansen test $(p)$ & 0.106 & 0.063 & 0.480 & 0.367 & 0.077 \\
\hline
\end{tabular}


Table 2 continued

\begin{tabular}{|c|c|c|c|c|c|}
\hline Dependent variable: $\ln$ sales & $\begin{array}{l}\text { Machinery \& } \\
\text { Equipment } \\
(\text { SIC35 + 36) }\end{array}$ & $\begin{array}{l}\text { Transport } \\
\text { equipment } \\
\text { (SIC37) }\end{array}$ & $\begin{array}{l}\text { Measuring } \\
\text { instrument } \\
\text { (SIC41) }\end{array}$ & $\begin{array}{l}\text { Other } \\
\text { manufacturing } \\
(\mathrm{SIC} 42+43)\end{array}$ & $\begin{array}{l}\text { Electronic } \\
\text { power } \\
\text { (SIC44) }\end{array}$ \\
\hline Returns-to-scale $(-1)$ & $0.181 * * *$ & $0.117 * * *$ & $0.224 *$ & -0.055 & $0.076^{* *}$ \\
\hline RTS (-1) Levinson-Petrin & 0.003 & -0.002 & $-0.012 * *$ & -0.005 & $-0.207 * * *$ \\
\hline Dependent variable: $\ln$ sales & & $\begin{array}{l}\text { Gas production } \\
\text { (SIC45) }\end{array}$ & \multicolumn{2}{|c|}{$\begin{array}{l}\text { Water production } \\
\text { (SIC46) }\end{array}$} & $\begin{array}{l}\text { Coal Mining } \\
\text { (SIC60) }\end{array}$ \\
\hline \multicolumn{6}{|l|}{ Panel E } \\
\hline In intermediate inputs & & $\begin{array}{l}0.265 * * * \\
(0.092)\end{array}$ & \multicolumn{2}{|c|}{$0.142 *$} & $\begin{array}{l}0.568 * * * \\
(0.027)\end{array}$ \\
\hline \multicolumn{2}{|l|}{ In employment } & $\begin{array}{l}0.348 * * * \\
(0.110)\end{array}$ & \multicolumn{2}{|c|}{$1.220 * * *$} & $\begin{array}{l}0.391 * * * \\
(0.062)\end{array}$ \\
\hline In capital & & $\begin{array}{l}0.461 * * * \\
(0.117)\end{array}$ & \multicolumn{2}{|c|}{$0.216^{* *}$} & $\begin{array}{l}0.083 * \\
(0.044)\end{array}$ \\
\hline Time trend & & $\begin{array}{l}0.081 * * * \\
(0.012)\end{array}$ & \multicolumn{2}{|c|}{$0.051 * * *$} & $\begin{array}{l}0.034 * * * \\
(0.004)\end{array}$ \\
\hline ln firm age & & $\begin{array}{l}-0.042 \\
(0.052)\end{array}$ & \multicolumn{2}{|c|}{$-0.221 * * *$} & $\begin{array}{l}-0.079 * * * \\
(0.016)\end{array}$ \\
\hline No political affiliation & & $\begin{array}{l}0.140 * * \\
(0.059)\end{array}$ & \multicolumn{2}{|c|}{$0.174 * * *$} & $\begin{array}{l}0.061 * * * \\
(0.011)\end{array}$ \\
\hline High political affiliation & & $\begin{array}{l}0.324 * * * \\
(0.121)\end{array}$ & \multicolumn{2}{|c|}{$0.239 * * *$} & $\begin{array}{l}-0.015 \\
(0.032)\end{array}$ \\
\hline p_capstate & & $\begin{array}{l}-0.226^{* *} \\
(0.092)\end{array}$ & \multicolumn{2}{|c|}{$-0.474 * * *$} & $\begin{array}{l}-0.212^{* * *} \\
(0.081)\end{array}$ \\
\hline p_capcoll & & $\begin{array}{l}0.297 * * \\
(0.132)\end{array}$ & $(0.146)$ & & $\begin{array}{l}-0.051 \\
(0.078)\end{array}$ \\
\hline p_capcorporate & & $\begin{array}{l}0.088 \\
(0.085)\end{array}$ & $(0.140)$ & & $\begin{array}{l}0.001 \\
(0.078)\end{array}$ \\
\hline p_capindividual & & $\begin{array}{l}0.206^{*} \\
(0.113)\end{array}$ & & & $\begin{array}{l}-0.012 \\
(0.078)\end{array}$ \\
\hline p_capforeign & & $\begin{array}{l}0.062 \\
(0.094)\end{array}$ & & & $\begin{array}{l}-0.234 \\
(0.146)\end{array}$ \\
\hline Exporter & & $\begin{array}{l}0.578 \\
(0.580)\end{array}$ & & & $\begin{array}{l}0.103 * * * \\
(0.027)\end{array}$ \\
\hline$R \& D$ dummy & & $\begin{array}{l}0.005 \\
(0.078)\end{array}$ & $\begin{array}{l}- \\
(0\end{array}$ & & $\begin{array}{l}0.238 * * * \\
(0.085)\end{array}$ \\
\hline ln agglomeration & & $\begin{array}{l}0.138 * * * \\
(0.043)\end{array}$ & & & $\begin{array}{l}0.103 * * * \\
(0.013)\end{array}$ \\
\hline ln Herfindahl & & $\begin{array}{l}0.205 * * \\
(0.089)\end{array}$ & $\begin{array}{l}0 . \\
(0\end{array}$ & & $\begin{array}{l}-0.247^{* * * *} \\
(0.023)\end{array}$ \\
\hline ln diversification & & $\begin{array}{l}0.188 * * * \\
(0.065)\end{array}$ & $\begin{array}{l}0 . \\
(0\end{array}$ & & $\begin{array}{l}0.019 * \\
(0.011)\end{array}$ \\
\hline ln fixed costs & & $\begin{array}{l}-0.100 * * * \\
(0.023)\end{array}$ & $\begin{array}{l}- \\
(0\end{array}$ & & $\begin{array}{l}-0.000 \\
(0.003)\end{array}$ \\
\hline Neg_liquid & & $\begin{array}{l}-0.022 \\
(0.035)\end{array}$ & $\begin{array}{l}- \\
(0\end{array}$ & & $\begin{array}{l}-0.044 * * * \\
(0.007)\end{array}$ \\
\hline ln liquidity & & $\begin{array}{l}0.789 * * * \\
(0.238)\end{array}$ & $\begin{array}{l}0 . \\
(0\end{array}$ & & $\begin{array}{l}0.376 * * * \\
(0.062)\end{array}$ \\
\hline
\end{tabular}


Table 2 continued

\begin{tabular}{llll}
\hline Dependent variable: $\ln$ sales & $\begin{array}{l}\text { Gas production } \\
(\text { SIC45) }\end{array}$ & $\begin{array}{l}\text { Water production } \\
(\text { SIC46) }\end{array}$ & $\begin{array}{l}\text { Coal Mining } \\
(\text { SIC60) }\end{array}$ \\
\hline CIty 200 & 0.057 & -0.033 & $-0.059 * * *$ \\
& $(0.057)$ & $(0.024)$ & $-4.078^{* * *}$ \\
Constant & -1.198 & $-8.343 * * *$ & $(1.278)$ \\
& $(0.886)$ & Yes & Yes \\
Province dummies & Yes & 19,451 & 32,920 \\
Observations & 2238 & 3183 & 10,866 \\
Number of firms & 695 & -8.935 & -17.743 \\
AR(1) z-statistic & -3.176 & 0 & 0 \\
AR(1) z-statistic $(p)$ & 0.001 & -0.642 & -1.644 \\
AR(2) z-statistic & -1.438 & 0.521 & 0.1 \\
AR(2) z-statistic $(p)$ & 0.150 & 11.26 & 6.614 \\
Hansen test & 27.83 & 0.258 & 0.251 \\
Hansen test $(p)$ & 0.114 & $0.578^{* * *}$ & 0.042 \\
Returns-to-scale $(-1)$ & 0.074 & $-0.072 * *$ & $-0.038^{* * *}$ \\
RTS $(-1)$ Levinson-Petrin & -0.050 & & \\
\hline
\end{tabular}

Sample period: 1998-2007; standard errors in parentheses

$* * * p<0.01 ; * * p<0.05 ; * p<0.1$

non-metal and metal products, transport equipment, and machinery and equipment than in industries like petroleum processing, textiles, plastic and leather, where the former are likely to be more dynamic and closer to the technological frontier.

Firm age is found to affect TFP significantly and negatively for most industries. This is consistent with the belief that younger firms produce with greater efficiency and better technology than older firms. Obviously the hypothesis that productivity increases as the firm ages through learning-by-doing is not supported by our data for China.

The coefficients of political affiliation show some interesting patterns. Firms with no political affiliation are found to have significantly higher TFP in most industries, which is in line with the view that the use of the invisible hand' of the market rather than government intervention is conducive to firm productivity in general. On the other hand, the coefficients of firms with high political affiliation vary significantly across industries. In some highly monopolistic industries such as gas and water production, the TFP effect of high political affiliation is significantly positive. This is because the Chinese government keeps a tight control on such sectors with strategic importance, and firms with high political affiliations can therefore enjoy more benefits such as a larger market share and more access to bank credit which may help them to maintain higher productivity levels. On the contrary, in other more competitive markets such as metal and nonmetal products, machinery and equipment, timber, and furniture, the TFP effect of high political affiliation is significantly negative, indicating that government intervention may distort firms' behavior and therefore reduce productivity.

In terms of ownership, we find that state ownership has a significant negative impact on TFP in general. This is consistent with the arguments that despite decades of economic reform, SOEs remain the least efficient group in the economy, with an average return on capital well below that in the private sector (Dougherty and Herd 2005; Ding et al. 2012). The effect of private ownership (individual investors and corporation/legal entities investors) on TFP is positive and significant for most industries, indicating that the private sector is the driving force of China's productivity and economic growth. An exception is found for some monopolistic sectors like medical, electronic power, and water production, where private ownership is associated with a negative (although often not significant) impact on TFP. As discussed above, this is because SOEs remain dominant in energy, natural resources and a few strategic or monopolistic sectors that are controlled and protected by central and local governments.

In a large number of sectors, foreign ownership is associated with higher levels of TFP. This is in line with the view of Hymer (1976) that to make it worthwhile for a foreign firm to incur the costs of setting up or acquiring a plant in the domestic market, foreign firms must possess characteristics that give them a cost advantage over domestic firms. But in the short-run there may be 'assimilation' issues (see discussion earlier) while in the long-run, some of these advantages may dissipate as domestically 
owned firms learn to imitate the foreign firms as a result of knowledge spillovers, depending upon levels of absorptive capacity in domestic firms (Harris and Robinson 2003). This argument may help to understand the insignificant coefficient of foreign ownership in some industries.

As stated above, the existing literature shows that exporting firms have superior performance compared to their non-exporting counterparts in terms of productivity, employment, wages, skill- and capital-intensity. This can be explained either through 'self-selection' or 'learning-byexporting' (see Bernard and Jensen 1999; Van Biesebroeck 2005; Bernard et al. 2007; De Loecker 2007). However, this view is not uniformly supported by our data, where exporters seem to have higher TFP in only 9 out of 26 sectors. There are at least three explanations for this seemingly surprising result, i.e. the processing trade argument; ${ }^{17}$ the financial constraints argument; and the factor endowments argument. First, one feature of China's trade pattern is the sheer magnitude of processing trade: about $60 \%$ of Chinese exports are in the processing trade sector during the period 2000-06 (Wang and Yu 2011). There is a recent literature on the effect of different trade regimes (ordinary vs. processing trade) on firm performance in China (for instance, Yu 2014; Manova and Yu 2012). Dai et al. (2011) find direct evidence that processing exporters are 4-30\% less productive than non-exporters, and that excluding processing trade restores the traditional finding that exporters have a superior performance relative to nonexporters. $^{18}$

Secondly, according to Manova and Zhang (2009), Chinese firms may face high fixed trade costs, which raise the productivity cut-off for exporting and importing. Despite being productive, some small firms may be unable to raise sufficient external financing to engage in international trade. Feenstra et al. (2013) confirm the view that unless they are foreign-owned, exporting firms face an additional credit constraint in China. Hence, it is likely that some productive Chinese firms are excluded from exporting markets due to financial constraints.

Thirdly, Lu (2010) offers an alternative explanation on the weak performance of Chinese exporters from the factor endowment view. He argues that when countries differ in their factor endowment, sectors that are intensive in the locally abundant factor face higher competition in the domestic market than in foreign markets. Hence it is

\footnotetext{
17 Processing trade refers to the activity of assembling tariff exempted imported inputs into final goods for resale in the foreign markets.

18 Jarreau and Poncet (2012) also claim that the growth-enhancing gains of trade are limited to the ordinary export activities undertaken by domestic firms, but not processing trade activities. Our results echo such findings and highlight the need to distinguish various trade regimes when examining the export-productivity nexus in China.
}

domestic rather than export markets that select the most productive firms. In a labor-abundant country like China, exporters are therefore likely to be less productive than non-exporters, especially in labor-intensive sectors.

Undertaking $R \& D$ is expected to have a positive impact on TFP through two channels discussed above (innovation and greater absorptive capacity). However, we find only limited supporting evidence for such hypotheses using Chinese NBS data: cet. par., R\&D leads directly to significantly higher TFP in only 9 out of 26 industries and leads to significantly lower TFP in transport equipment (although as shown below in Fig. 6, overall firms engaging in $\mathrm{R} \& \mathrm{D}$ do have a productivity advantage over those that spend nothing on such intangible, knowledge-based assets). It is difficult to provide further details with regard to the results obtained, given that we are not aware of any studies that have looked at the impact of $R \& D$ for the disaggregated set of industries included in this study (and specially transport equipment). Others have positive results for sectors like electronics (e.g., Yang et al. 2013), or overall across all industries (e.g., Liao et al. 2012). This study also finds positive spillover effects (see below) through agglomeration and diversification, and these effects are likely to be (at least in part) associated with knowledge spillovers (and therefore linked to $R \& D$ ).

In this study we proxy MAR-spillovers using an agglomeration variable, i.e. the logarithm of the percentage of 2-digit industry output located in each province in which the firm is located. ${ }^{19}$ Jacobian spillovers, on the other hand, are proxied by a measure of diversification, i.e. the logarithm of the proportion of 3-digit industries (maximum 226) located in (208) city areas in which the firm is located. ${ }^{20}$ In general, we find agglomeration spillovers are significant and positive (in 18 out of 26 industries), especially in non-metal products, other mining, medical, gas production, timber, furniture, petroleum processing, coal mining and electricity. Diversification spillovers are even stronger both in terms of the number of industries in which there is a significant positive effect (only the tobacco industry and electronic power has no such impact), and the strength of the relationship (in 9 industries a $10 \%$ increase in diversification results in at least a $2 \%$ increase in TFP). We also include a dummy that takes on a value of 1 for

\footnotetext{
19 Specifically, $\ln 100 \times \sum_{i \in j}\left(\frac{y_{i}}{\sum_{i} y_{i}}\right)_{m}$ where firm $i$ belongs to 2-digit industry $j$, located in province $m$. This gives $j \times m$ unique observations for each year which are mapped to each firm $i$ in year $t$.

${ }^{20}$ Specifically, for each city area, the number of industries present in the city are divided by 226 . Note that we use a 3-digit breakdown (and city areas rather than provinces) to obtain as accurate a measure as possible. For the agglomeration index, we had to use a more aggregated level for both industry and area, to avoid non-zero cells where there are no observations for an industry in a particular area.
} 
those firms located in one of the top 200 cities (based on population size), as an additional proxy for potential negative spillovers (i.e. 'congestion' costs) in large Chinese cities. We find that in 19 of the 26 industries covered, there exist such significant costs (ranging between 5 and $14 \%$ ).

Including the Herfindahl index, we find that higher competition within some industries leads to lower TFP in 9 industries (especially in textiles, cultural, and gas production), but higher TFP in the majority (14 out of 26 industries, especially food production, petroleum processing, coal mining, medical and nonmetal products). Our proxy for managerial fixed costs, i.e. selling and distribution expenses as a percentage of sales, shows that the higher these are, the lower is TFP in 23 out of 26 industries.

Finally, in line with Chen et al. (2011), we include two measures of liquidity in our equation. We measure liquidity as the difference between current assets and current liabilities. ${ }^{21}$ We also include a dummy (coded 1) to distinguish those firms that have zero or negative liquidity. We find that firms that experiencing negative liquidity in any year are associated with a significantly lower TFP in almost every industry (usually the impact is to lower TFP by some 4-6\%). In addition, the higher the working capital, the higher TFP in all but one industry (the largest effect is in nonmetal products, where a $10 \%$ increase in liquidity results in a $12 \%$ higher level of TFP). These findings can be explained considering that firms with high (low) liquidity are less (more) likely to face financial constraints and have more (less) resources at hand to undertake productivity-enhancing activities (Chen and Guariglia 2013).

In brief, our production function estimation based on the system GMM estimator indicates increasing returns to scale in most industries and significant technical change. Younger firms and firms with no political affiliation are found to have higher TFP, and firms with state ownership are found to have lower TFP. There exists some heterogeneous evidence among industries on the effect of high political affiliation and private ownership (individual investors and corporation investors/legal entities), which seems plausible in the Chinese institutional context. Neither being an exporter nor investing in $R \& D$ are found to impact strongly on TFP among most industries, but there is evidence of positive agglomeration spillovers (counted to some extent by negative 'costs' associated with the very largest urban areas). Firm fixed costs and liquidity are also important, in ways consistent with prior expectations.

\footnotetext{
${ }^{21}$ Since current liabilities can exceed current assets, leading to negative liquidity and since the variable is logged, we add 1 to this ratio.
}

\subsection{TFP distributions}

We next present a graphical analysis highlighting TFP differences over time, across firms with different characteristics, and across provinces. To this end, we order the predicted TFP values (based on Eq. 2a) from highest-tolowest. Figure 1 shows the productivity distribution for firms operating in 1998 and in 2007. We can see that the distribution of 2007 obviously dominates (i.e. lies to the right) that of 1998, showing direct evidence of productivity growth. A formal test that the 2007 distribution lies to the right (i.e. stochastically dominates) that of 1998 is provided by the Kolmogorov-Smirnov (KS) test, which indicates the maximum gap between the two distributions is nearly 0.17 and statistically significant at the $1 \%$ level.

Figure 2 compares the productivity distribution between firms with high political affiliation (those affiliated with central and provincial governments) and firms with lesser or no links. Consistent with the results in Table 2, firms with no political affiliation have a productivity distribution to the right of those with high political affiliation, indicating that the former dominates the latter in terms of its TFP distribution (a KS test shows that the maximum gap between the distribution for firms with no affiliation and firms with some affiliation has a value of $0.18,{ }^{22}$ and is significant at the $1 \%$ level). Figure 3 compares the distribution of firms with more than $25 \%$ of state ownership and those with less than $25 \%$ of state ownership. We observe that the TFP distribution of those with less state ownership dominates that of firms with more state ownership with a highly significant KS value of 0.33 . This is again consistent with our findings in Table 2.

Contrasting TFP distributions also shows significant heterogeneity among various geographic locations. For instance, Fig. 4 compares the TFP distribution of east coast Shanghai and that of an inner province, Guizhou. Not surprisingly, Shanghai has a productivity distribution to the right of Guizhou (the value of the KS test statistic is 0.41 , significant at the $1 \%$ level). Hence it is important to capture such geographic information when estimating TFP.

Lastly, Fig. 5 shows some evidence of significant crossover in terms of TFP distribution between exporters and non-exporters, at the top end of the productivity distribution, although, overall, firms engaged in exporting tend to have higher productivity. Similar results are found for firms undertaking R\&D (Fig. 6), where the productivity advantage is much smaller (significant at the $1 \%$ level, but with a KS statistic of 0.09). These findings are in line with the econometric results in Table 2.

\footnotetext{
${ }^{22}$ This represents the largest proportional gap between the two distributions.
} 


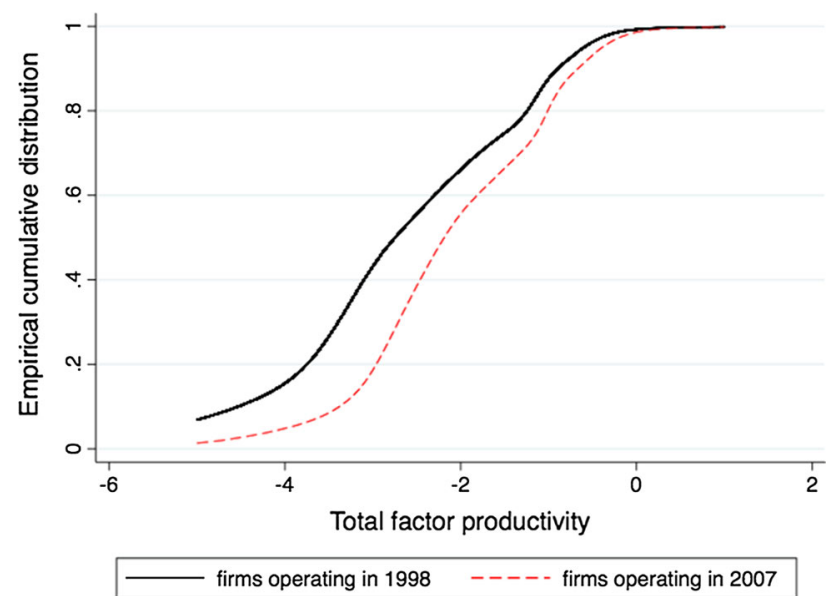

Fig. 1 TFP distribution: 1998 versus 2007

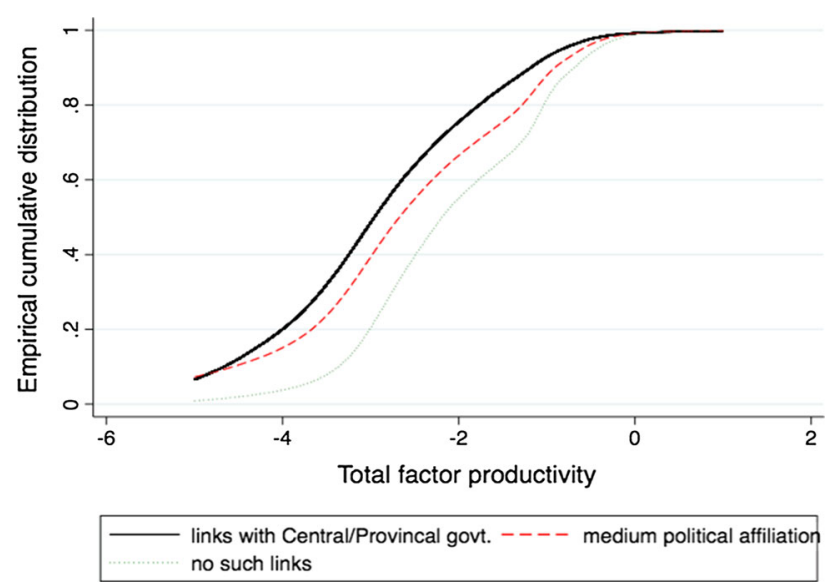

Fig. 2 TFP distribution: high political affiliation versus no political affiliation

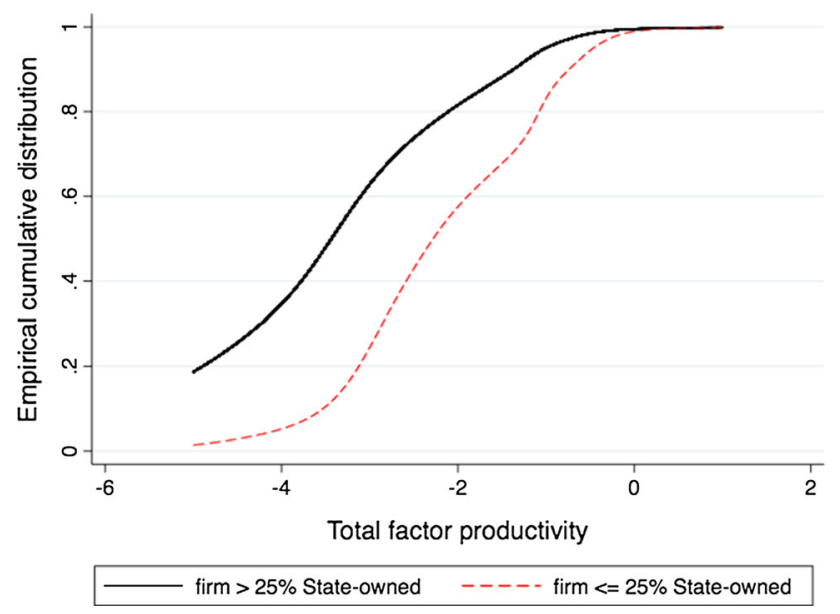

Fig. 3 TFP distribution: ownership comparison

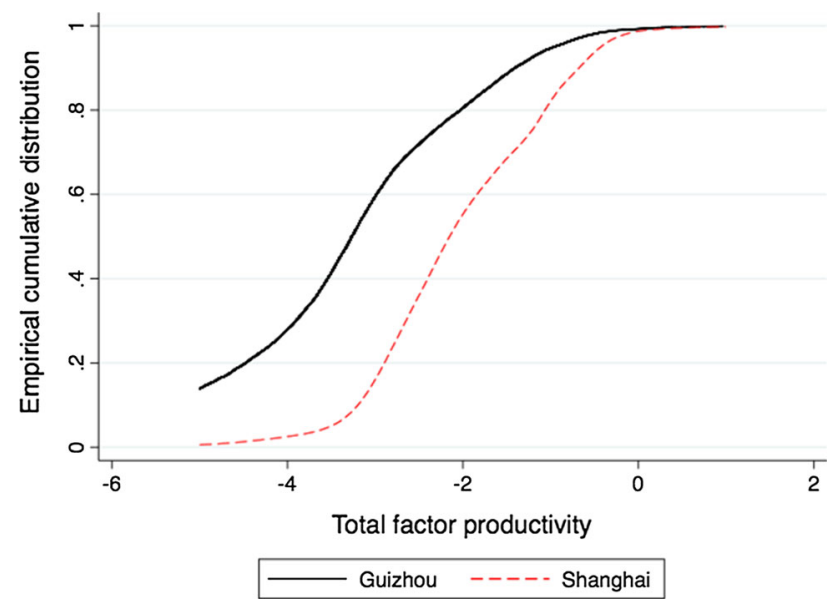

Fig. 4 TFP distribution: geographic location comparison

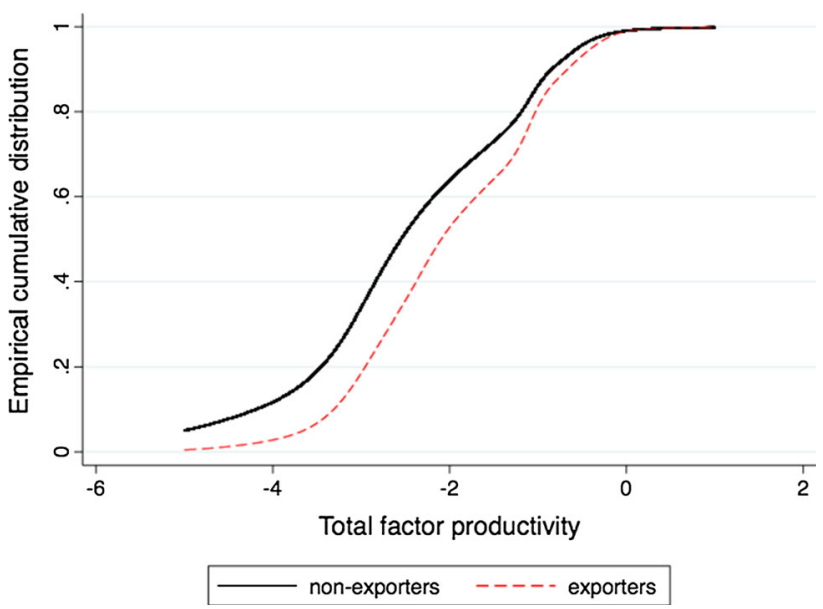

Fig. 5 TFP distribution: exporters versus non-exporters

\section{Productivity decomposition}

\subsection{The Haltiwanger (1997) approach and some baseline results}

Having obtained firm-level estimates of TFP, we use the approach taken by Haltiwanger to decompose measures of productivity growth into various components that represent the impact of resource allocation across surviving firms, as well the impact on productivity of the entry and exit of firms. ${ }^{23}$ The index of productivity in year $t$ is defined as a geometrically weighted average of individual firm-level productivities. This index and its growth between $t$ and $t-k$ can therefore be written as follows:

\footnotetext{
23 There are different decomposition approaches, which can produce different results (e.g., Disney et al. 2003), We favour the Haltiwanger approach, which is reviewed and contrasted in Foster et al. (1998) and Disney et al. (2003) who argue in its favour.
} 


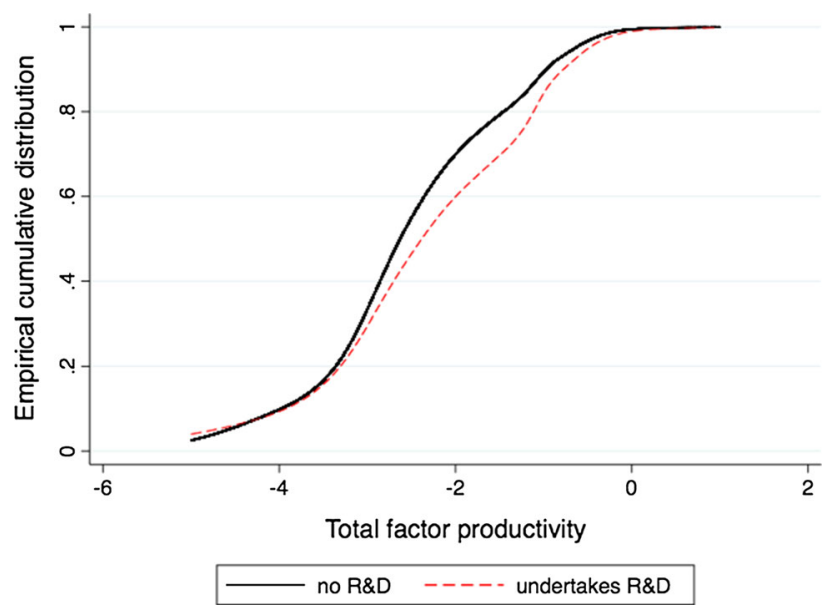

Fig. 6 TFP distribution: $R \& D$ versus no $R \& D$

$\ln P_{t}=\sum_{i} \theta_{i t} \ln P_{i t} \quad \Delta \ln P_{t}=\ln P_{t}-\ln P_{t-k}$

where $P$ measures productivity and $\theta_{i t}$ is the share of output for firm $i$ in period $t$ for the economy. The decomposition for a given economy is motivated by the fact that there are firms that continue in operation between $t$ and $t-k$, new firms entering in period $t$, as well as firms exiting, which all contribute to productivity in $t-k$. Thus, productivity growth can be expressed as follows:

$$
\begin{aligned}
\Delta \ln P_{t}= & \sum_{i}^{\text {Continuers: within-firm }} \theta_{i t-k} \Delta \ln P_{i t}+\sum_{i}\left(\ln P_{i t-k}-\ln P_{t-k}\right) \Delta \theta_{i t} \\
& +\sum_{i}^{\text {Continuers: Cross-firm }} \Delta \ln P_{i t} \Delta \theta_{i t}+\sum_{i} \theta_{i t}\left(\ln P_{i t}-\ln P_{t-k}\right) \\
& -\sum_{i} \theta_{i t-k}\left(\ln P_{i t}-\ln P_{t-k}\right)
\end{aligned}
$$

The first term shows the impact of resource shifts within firms that were open in both $t$ and $t-k$ to achieve higher (or lower) productivity, depending on how important such firms were in the base year (in terms of their shares of output in the economy). The second term also concerns continuing firms, and measures the impact of changing productivity shares across firms weighted by the firm's ranking in the economy in the base year. The second term needs to be complemented with the third: the covariance effect that considers whether increases in productivity correspond (covary) with increasing market shares. Lastly, there are terms to denote the contributions of entrants and exiting firms, both measured with respect to the economy average in the base year. It should be noted that the last term is expected to be negative if exiting firms have lower productivity. Thus, this term is preceded by a negative sign to allow for a positive impact on productivity. ${ }^{24}$

\footnotetext{
${ }^{24}$ We impose this negative sign in the tables below to make it easier to interpret the results.
}

In summary, the Haltiwanger-type decomposition disaggregates changes in total productivity into those due to within-firm increases, those due to between-firm increases, ${ }^{25}$ and the share of new entrants and those firms exiting production. Note that compared to standard indices, the more general Haltiwanger-type approach provides a holistic view of the interaction of firms, industries, and the aggregate economy, since firm entry and exit in markets inherently involves changes in market shares, and thus industrial restructuring. That is, when describing aggregate productivity growth, we need to include and measure the impact of such 'churning', as well as the impact on TFP of any intra-industry reallocations of resources.

The approach can also be used to show the relative contributions of various sub-groups (e.g. industry sectors) to overall TFP growth, as well as decomposing TFP growth into its sources (intra-, inter-resource reallocations, as well as the impact of entry and exit). However, if there are a large number of sub-groups being considered (and/or any have a non-equal share in total aggregate output), then the figures obtained can be somewhat difficult to interpret, i.e. they are determined not only by what has been happening to TFP in a sector but also how important the sector is to the economy, in terms of its share of total output. Therefore to help interpret such Haltiwanger results, we produce not only the figures obtained from the Haltiwanger decomposition (row 1 in Tables 4,5) but also these figures weighted to take account of the relative size of each sector (rows 2-6 in Tables 4, 5). ${ }^{26}$

We start by producing the overall results for all the industries that are covered in the NBS dataset. Table 3 shows that, based on the system GMM estimation, annual growth in TFP between 1998 and 2007 in Chinese industries was overall $10 \%$. As can be seen, this very large TFP growth was dominated by new firms entering post- 1998 with relatively higher TFP. This finding is consistent with (although slightly stronger than) the conclusion by Brandt et al. (2012) that net entry accounts for over two thirds of total TFP growth. There was no increased productivity through the exit of firms with relatively lower TFP (indeed on average more productive firms closed); and improvements due to firms becoming themselves more productive over time were relatively small (although not small when compared with the UK). Reallocations of resources

\footnotetext{
${ }^{25}$ We have combined the between-firm and cross-firm effects obtained from the Haltiwanger approach into one 'between firm' effect. While the separate information is of some interest, we are mainly concerned with whether there were changes in TFP within firms, between firms, or through entry and exit.

${ }^{26}$ Obviously when producing results for all industries, the weighted and actual figures are the same. But as will be seen below, when we sub-divide firms into different sub-groups, the results then differ given the relative size of each sub-group in the total economy covered.
} 
Table 3 Firm-level TFP growth (average $\%$ p.a.) in Chinese (1998-2007) and UK industry (1997-2008)

\begin{tabular}{lcrr}
\hline Haltiwanger approach & \multicolumn{2}{l}{ China } & $\mathrm{UK}^{\mathrm{b}}$ \\
\cline { 2 - 3 } & SYS-GMM & LevPet & \\
\hline Actual TFP growth & 9.52 & 3.17 & 1.20 \\
Decomposition of TFP & growth & & \\
Within firm $^{\text {Between firm }}{ }^{\mathrm{a}}$ & 2.54 & 0.45 & 0.60 \\
Enterers $_{\text {Exitors }}$ & 1.94 & 0.66 & 0.63 \\
\hline
\end{tabular}

${ }^{a}$ We have combined the second and third terms on the right-handside of the equal sign in Eq. (6)

b The UK figures refer to manufacturing and cover 1997-2008 (source: based on Harris and Moffat 2012, Table 5.1) (through contraction and expansion of output shares in firms of different productivity levels) also contributed relatively little to raising aggregate TFP growth. The corresponding figures based on the Levinsohn and Petrin (2003) approach are much lower, e.g. $3.4 \%$ for the annual TFP growth, but the main finding that firm entry contributes to TFP growth in China remains intact.

For comparison, we have included in Table 3 figures for UK manufacturing, which are based on the same type of approach as used here (both in terms of deriving estimates of TFP and the use of the Haltiwanger approach). The major difference between China and the UK is that TFP growth was on average $10 \%$ per annum in China, versus $1.2 \%$ per annum in the UK. The importance of entry dominates TFP growth in both countries (and in others,

Table 4 Firm-level TFP growth (average per annum) in industry sub-sectors, 1998-2007, China

\begin{tabular}{|c|c|c|c|c|c|c|c|c|}
\hline \multirow[t]{2}{*}{ Sector } & \multicolumn{2}{|c|}{ TFP growth (\% p.a.) } & \multicolumn{4}{|c|}{ Decomposition of (weighted) TFP growth } & \multicolumn{2}{|c|}{ Output share $(\%)$} \\
\hline & $\begin{array}{l}\text { Actual } \\
\text { (1) }\end{array}$ & $\begin{array}{l}\text { Weighted }{ }^{a} \\
\text { (2) }\end{array}$ & $\begin{array}{l}\text { Within firm } \\
\text { (3) }\end{array}$ & $\begin{array}{l}\text { Between firm }{ }^{b} \\
\text { (4) }\end{array}$ & $\begin{array}{l}\text { Enterers } \\
\text { (5) }\end{array}$ & $\begin{array}{l}\text { Exitors } \\
(6)\end{array}$ & $\begin{array}{l}1998 \\
\text { (7) }\end{array}$ & $\begin{array}{l}2007 \\
(8)\end{array}$ \\
\hline Water production & 0.16 & 30.72 & 3.32 & 17.47 & -4.31 & -14.25 & 0.5 & 0.2 \\
\hline Measuring instrument & 0.80 & 18.15 & 1.80 & 3.16 & 15.18 & 1.98 & 4.4 & 7.3 \\
\hline Metal products & 2.20 & 15.55 & 2.90 & 3.45 & 13.99 & 4.79 & 14.2 & 18.3 \\
\hline Petroleum processing & 1.51 & 15.45 & 2.81 & 9.99 & -2.13 & -4.78 & 9.8 & 3.4 \\
\hline Machinery and equipment & 0.96 & 14.07 & 4.53 & 2.16 & 4.32 & -3.06 & 6.8 & 11.5 \\
\hline Transport equipment & 0.91 & 13.50 & 4.75 & 0.95 & 7.46 & -0.33 & 6.8 & 9.0 \\
\hline Gas production & 0.04 & 13.10 & 2.27 & 0.75 & 10.26 & 0.18 & 0.3 & 0.3 \\
\hline Other mining & 0.19 & 12.45 & 4.96 & 1.82 & -2.47 & -8.15 & 1.5 & 1.8 \\
\hline Nonmetal products & 0.63 & 11.88 & 2.83 & 0.72 & 7.63 & -0.71 & 5.3 & 5.2 \\
\hline Electric power and heating & 0.93 & 11.53 & 6.24 & 2.19 & -1.83 & -4.93 & 8.1 & 6.7 \\
\hline Medical & 0.25 & 10.86 & 2.90 & 3.99 & -4.57 & -8.55 & 2.3 & 1.8 \\
\hline Coal mining & 0.22 & 8.51 & 3.42 & 1.27 & 1.47 & -2.35 & 2.6 & 2.3 \\
\hline Food production & 0.14 & 8.13 & 2.12 & -0.87 & 10.37 & 3.49 & 1.8 & 1.8 \\
\hline Chemical & 0.67 & 6.99 & 1.31 & 1.28 & 2.16 & -2.23 & 9.6 & 8.4 \\
\hline Furniture & 0.02 & 4.16 & 0.59 & 0.76 & 0.00 & -2.81 & 0.5 & 0.7 \\
\hline Tobacco & 0.10 & 4.08 & 3.46 & -0.72 & 0.79 & -0.55 & 2.5 & 1.2 \\
\hline Apparel, footwear & 0.11 & 3.70 & 2.45 & -0.76 & 4.94 & 2.93 & 3.1 & 2.8 \\
\hline Timber & 0.03 & 3.61 & 1.29 & 1.04 & -4.12 & -5.40 & 0.8 & 1.2 \\
\hline Rubber & 0.03 & 2.52 & 1.25 & 0.11 & 4.91 & 3.75 & 1.3 & 1.1 \\
\hline Papermaking & 0.03 & 1.39 & 0.25 & -0.82 & 11.64 & 9.69 & 2.1 & 2.0 \\
\hline Cultural & 0.00 & 0.49 & 2.40 & -4.09 & 6.58 & 4.40 & 0.9 & 0.7 \\
\hline Printing & -0.01 & -0.82 & 0.78 & -3.65 & 7.52 & 5.47 & 0.9 & 0.6 \\
\hline Plastic & -0.02 & -0.85 & -1.66 & -2.92 & 16.16 & 12.43 & 2.4 & 2.4 \\
\hline Textile & -0.15 & -2.04 & -0.15 & -1.82 & 10.60 & 10.68 & 7.3 & 6.1 \\
\hline Leather & -0.05 & -2.66 & -0.16 & -4.60 & 16.22 & 14.13 & 1.9 & 1.6 \\
\hline \multirow[t]{2}{*}{ Other manufacturing } & -0.21 & -8.48 & -4.02 & -1.66 & 6.70 & 9.51 & 2.4 & 1.6 \\
\hline & 9.52 & 9.52 & 2.54 & 1.94 & 6.00 & 0.96 & 100 & 100 \\
\hline
\end{tabular}

${ }^{a}$ Column (1) divided by column $(7) \div 100$. Note, figures are based on underlying data (note rounded data presented here)

b We have combined the second and third terms on the right-hand-side of the equal sign in Eq. (6) 
Table 5 Firm-level TFP growth (average per annum) in provinces, 1998-2007, China

\begin{tabular}{|c|c|c|c|c|c|c|c|c|}
\hline \multirow[t]{2}{*}{ Province } & \multicolumn{2}{|c|}{ TFP growth (\% p.a.) } & \multicolumn{4}{|c|}{ Decomposition of (weighted) TFP growth } & \multicolumn{2}{|c|}{ Output share $(\%)$} \\
\hline & $\begin{array}{l}\text { Actual } \\
\text { (1) }\end{array}$ & $\begin{array}{l}\text { Weighted }{ }^{a} \\
\text { (2) }\end{array}$ & $\begin{array}{l}\text { Within firm } \\
\text { (3) }\end{array}$ & $\begin{array}{l}\text { Between firm }{ }^{\mathrm{b}} \\
\text { (4) }\end{array}$ & $\begin{array}{l}\text { Enterers } \\
(5)\end{array}$ & $\begin{array}{l}\text { Exitors } \\
(6)\end{array}$ & $\begin{array}{l}1998 \\
(7)\end{array}$ & $\begin{array}{l}2007 \\
(8)\end{array}$ \\
\hline Jiangxi & 0.31 & 25.09 & 5.78 & 3.87 & 12.75 & -2.69 & 1.2 & 2.0 \\
\hline Inner Mongolia & 0.18 & 20.97 & 5.21 & -1.22 & 14.92 & -2.07 & 0.8 & 1.5 \\
\hline Shandong & 1.35 & 15.29 & 3.32 & 3.31 & 8.34 & -0.32 & 8.8 & 12.6 \\
\hline Gansu & 0.15 & 15.27 & 4.13 & 5.67 & 0.26 & -5.22 & 1.0 & 0.8 \\
\hline Beijing & 0.37 & 14.28 & 5.05 & 4.33 & 5.56 & 0.66 & 2.6 & 3.1 \\
\hline Qinghai & 0.03 & 13.80 & 2.65 & 0.62 & -0.04 & -10.58 & 0.3 & 0.2 \\
\hline Xinjiang & 0.17 & 12.60 & 1.67 & 9.87 & -0.23 & -1.28 & 1.3 & 0.6 \\
\hline Hunan & 0.21 & 12.08 & 2.28 & 2.01 & 7.54 & -0.23 & 1.8 & 1.9 \\
\hline Chongqing & 0.15 & 11.97 & 2.57 & 0.75 & 5.69 & -2.96 & 1.2 & 1.2 \\
\hline Sichuan & 0.29 & 11.84 & 3.70 & 3.03 & 4.40 & -0.70 & 2.5 & 2.4 \\
\hline Liaoning & 0.60 & 11.28 & 2.63 & 4.50 & 3.87 & -0.28 & 5.3 & 4.4 \\
\hline Anhui & 0.25 & 11.22 & 4.31 & 2.97 & 4.65 & 0.72 & 2.2 & 2.1 \\
\hline Henan & 0.53 & 11.03 & 3.19 & 3.61 & 5.16 & 0.94 & 4.8 & 5.0 \\
\hline Shanxi & 0.19 & 10.96 & 3.63 & 2.94 & 1.53 & -2.85 & 1.7 & 1.9 \\
\hline Heilongjiang & 0.36 & 10.66 & 0.08 & 8.84 & 0.21 & -1.53 & 3.3 & 0.9 \\
\hline Hebei & 0.51 & 10.46 & 1.94 & 3.98 & 5.94 & 1.40 & 4.9 & 4.7 \\
\hline Jilin & 0.19 & 9.90 & 4.05 & 1.21 & 2.34 & -2.30 & 1.9 & 1.3 \\
\hline Guangxi & 0.12 & 9.77 & 3.61 & 1.25 & 4.22 & -0.69 & 1.3 & 1.1 \\
\hline Shaanxi & 0.11 & 9.58 & 3.85 & 2.80 & 1.15 & -1.78 & 1.1 & 1.1 \\
\hline Hainan & 0.02 & 9.48 & 2.88 & -2.56 & 7.44 & -1.72 & 0.2 & 0.2 \\
\hline Zhejiang & 0.58 & 8.84 & 1.46 & 0.87 & 10.16 & 3.65 & 6.6 & 9.1 \\
\hline Ningxia & 0.03 & 8.55 & 1.48 & 0.52 & 2.35 & -4.20 & 0.4 & 0.2 \\
\hline Tianjin & 0.25 & 8.41 & 2.92 & 2.11 & 5.84 & 2.46 & 3.0 & 2.5 \\
\hline Jiangsu & 1.01 & 8.29 & 2.19 & 1.42 & 7.38 & 2.70 & 12.2 & 13.2 \\
\hline Fujian & 0.22 & 8.22 & 2.45 & -0.83 & 8.70 & 2.10 & 2.6 & 3.2 \\
\hline Guizhou & 0.05 & 6.33 & 2.99 & -0.08 & 1.90 & -1.53 & 0.7 & 0.6 \\
\hline Hubei & 0.21 & 5.72 & 2.16 & 2.34 & 2.60 & 1.38 & 3.6 & 2.4 \\
\hline Yunnan & 0.11 & 5.72 & 2.13 & -1.13 & 2.50 & -2.22 & 1.9 & 1.2 \\
\hline Guangdong & 0.61 & 4.79 & 1.19 & -0.92 & 6.99 & 2.48 & 12.7 & 12.0 \\
\hline \multirow[t]{2}{*}{ Shanghai } & 0.39 & 4.76 & 2.94 & -1.35 & 6.17 & 3.00 & 8.2 & 6.7 \\
\hline & 9.52 & 9.52 & 2.54 & 1.94 & 6.00 & 0.96 & 100 & 100 \\
\hline
\end{tabular}

${ }^{a}$ Column (1) divided by column $(7) \div 100$. Note, figures are based on underlying data (note rounded data presented here)

b We have combined the second and third terms on the right-hand-side of the equal sign in Eq. (6)

given the results reported for many countries in the last decade); while productivity improvements in firms open in both 1997 and 2008 (the continuers) made a relatively important contribution to UK manufacturing, but not to Chinese manufacturing. Contrary to China, firms closing in the UK had on average higher TFP, and thus their closure lowered aggregate TFP.

\subsection{Results for the industry sub-sectors and provinces}

Table 4 presents the industry-level results of productivity decomposition. Column (1) presents the actual growth in
TFP obtained using Eq. (5). The industry sub-group figures sum to the total for all sectors. This does not take into account differences in the relative size of each sub-group (columns 7 and 8), and therefore column (2) is based on weighting column (1) by output shares in the base year. Columns (3)-(6) present the results obtained from applying the Haltiwanger-type decomposition (Eq. 5) and each row sums to the figures in column (2).

The results show that between 1998 and 2007, TFP increased by $10 \%$ per annum on average across all sectors with, in terms of absolute contributions to TFP growth (column 1), petroleum processing contributing the most, followed by metal products, and machinery and equipment. 
Taking into account the relative size of each sector (column 2), water production is the largest contributor to TFP growth, followed by petroleum processing, and machinery and equipment. The largest decline in TFP (in both relative and absolute terms) is attributable to other manufacturing.

In terms of the decomposition of TFP growth, the figures in columns (3) to (6) show that, in general, 'churning' (firm entry and exit) dominates. Sectors that experienced rapid TFP growth are dominated by either the opening of more productive firms (e.g. and machinery and equipment, metal products, transport equipment, gas production, and measuring instruments); or the closing of less productive firms (e.g. water production, non-metal products, electronic power and heating, medical and other mining). For sectors characterized by relatively low (or even negative) TFP growth (i.e. the lower half of Table 4), the most important contributions are the closing of relatively high productivity firms and reallocations of output to less efficient firms operating throughout the period (i.e., the between-firm effect). In general the within-firm effect is relatively unimportant in explaining TFP growth at the industry-level.

Table 5 presents the results for provinces. In column (2), where the TFP growth is weighted by output shares in different provinces, it is interesting to see that several inner provinces such as Inner Mongolia, Xinjiang, Heilongjiang, Gansu and Qinghai are ranked in the top half of the table in terms of relative contributions to TFP growth. Their rapid TFP growth may reflect a catch-up effect among Chinese provinces, which is also experienced by provinces just inland from the east coast provinces (e.g. Jiangxi, Hunan, and Hebei). Others have found similar evidence (e.g. the recent studies by Andersson et al. 2013; Herrerias and Ordonez 2012), although it is difficult to make direct comparisons as these studies use different time periods, measures based on labour productivity (not TFP), and aggregate (not firm-level) data.

\section{Conclusion}

Drawing on a large firm-level dataset, we examine TFP and its determinants in Chinese industries over the period of 1998-2007. When estimating TFP, we favor the system GMM estimator because of its ability to capture firm-level fixed effects and to deal with the endogeneity of regressors and potential mis-measurement. Besides the factor inputs, we include in the production function several Chinaspecific variables such as firms' political affiliation and ownership, along with some other general variables such as firm age, export behavior, intangible fixed assets (proxied by $R \& D)$, liquidity, and geographic location, in order to alleviate the omitted variable(s) problem. TFP is estimated separately for each industry to allow for heterogeneity in technology. A Haltiwanger approach is then adopted to decompose TFP growth into different components for both the economy and for various sub-sectors.

In brief, our production function estimation based on the system GMM estimator indicates increasing returns to scale in most industries and significant technical change. Younger firms and firms with no political affiliation are found to have higher TFP, and firms with state ownership are found to have lower TFP. There exists some heterogeneous evidence among industries on the effect of high political affiliation and private ownership (individual investors and corporation investors/legal entities), which seems plausible in the Chinese institutional context. Neither export behavior nor R\&D are found to impact strongly on TFP among most industries, but there is evidence of positive agglomeration spillovers (countered to some extent by negative 'costs' associated with the very largest urban areas). Firm fixed costs and liquidity are also important. Our estimated average TFP growth in Chinese industries is $10 \%$ per annum over the sample period. The Haltiwanger-type decomposition shows that this rapid productivity growth is mainly driven by firm entry rather than reallocation among existing firms. When an industry- and province-level decomposition is conducted, it appears that the positively contributing inter-firm resource reallocations are more prominent across industries than across provinces.

Open Access This article is distributed under the terms of the Creative Commons Attribution 4.0 International License (http://creative commons.org/licenses/by/4.0/), which permits unrestricted use, distribution, and reproduction in any medium, provided you give appropriate credit to the original author(s) and the source, provide a link to the Creative Commons license, and indicate if changes were made.

\section{Appendix}

See Table 6.

Table 6 Structure of our unbalanced panel

\begin{tabular}{lclc}
\hline Year & Number of observations & Percent & Cumulative \\
\hline Panel I & & & 6.8 \\
1998 & 148,474 & 6.8 & 13.6 \\
1999 & 148,474 & 7.4 & 21.0 \\
2000 & 162,004 & 6.8 & \\
\hline
\end{tabular}


Table 6 continued

\begin{tabular}{|c|c|c|c|c|c|c|}
\hline Year & \multicolumn{3}{|c|}{ Number of observations } & Percent & & Cumulative \\
\hline 2001 & \multicolumn{3}{|l|}{168,275} & \multicolumn{2}{|l|}{7.7} & 28.7 \\
\hline 2002 & \multicolumn{3}{|l|}{180,751} & \multicolumn{2}{|l|}{8.3} & 37.0 \\
\hline 2003 & \multicolumn{3}{|l|}{195,389} & \multicolumn{2}{|l|}{9.0} & 46.0 \\
\hline 2004 & \multicolumn{3}{|l|}{277,827} & \multicolumn{2}{|l|}{12.7} & 58.7 \\
\hline 2005 & \multicolumn{3}{|l|}{270,564} & \multicolumn{2}{|l|}{12.4} & 71.1 \\
\hline 2006 & \multicolumn{3}{|l|}{300,498} & \multicolumn{2}{|l|}{13.8} & 84.8 \\
\hline 2007 & \multicolumn{3}{|l|}{331,453} & \multicolumn{2}{|l|}{15.2} & 100 \\
\hline Total & \multicolumn{3}{|l|}{$2,183,709$} & \multicolumn{2}{|l|}{100} & \\
\hline Number of observations per firm & Number of firms & Percent & Cumulative & Number of firm-year observations & Percent & Cumulative \\
\hline \multicolumn{7}{|l|}{ Panel II } \\
\hline 1 & 109,513 & 19.6 & 19.6 & 109,513 & 5.0 & 5.0 \\
\hline 2 & 103,878 & 18.6 & 38.1 & 207,756 & 9.5 & 14.5 \\
\hline 3 & 74,800 & 13.4 & 51.5 & 224,400 & 10.3 & 24.8 \\
\hline 4 & 98,547 & 17.6 & 69.1 & 394,188 & 18.1 & 42.9 \\
\hline 5 & 41,828 & 7.5 & 76.6 & 209,140 & 9.6 & 52.4 \\
\hline 6 & 36,373 & 6.5 & 83.1 & 218,238 & 10.0 & 62.4 \\
\hline 7 & 26,356 & 4.7 & 87.8 & 184,492 & 8.4 & 70.9 \\
\hline 8 & 19,746 & 3.5 & 91.3 & 157,968 & 7.2 & 78.1 \\
\hline 9 & 8,616 & 1.5 & 92.8 & 77,544 & 3.6 & 81.7 \\
\hline 10 & 40,047 & 7.2 & 100 & 400,470 & 18.3 & 100.0 \\
\hline Total & 559,704 & 100 & & $2,183,709$ & 100 & \\
\hline
\end{tabular}

\section{References}

Ackerberg D, Caves K, Frazer G (2006) Structural identification of production functions. UCLA mimeo

Aghion P, Howitt P (1992) A model of growth through creative destruction. Econometrica 60:323-351

Aghion P, Howitt P (1999) Endogenous growth theory. MIT Press, Cambridge

Aghion P, Harris C, Howitt P, Vickers J (2001) Competition, imitation and growth with step-by-step innovation. Rev Econ Stud 68:467-492

Andersson FNG, Edgerton DL, Opper S (2013) A matter of time: revisiting growth convergence in China. World Dev 45:239-251

Arellano M, Bond S (1991) Some tests of specification for panel data: Monte Carlo evidence and an application to employment equations. Rev Econ Stud 58(2):277-297

Arrow KJ (1962) The economic implications of learning by doing. Rev Econ Stud 29:155-173

Bartelsman EJ, Dhrymes PJ (1998) Productivity dynamics: U.S. manufacturing plants, 1972-1986. J Prod Anal 9:5-34

Bas M, Causa O (2013) Trade and product market policies in upstream sectors and productivity in downstream sectors: firmlevel evidence from China. J Comp Econ 41:843-862

Bernard AB, Jensen BJ (1999) Exceptional exporter performance: cause, effect, or both? J Int Econ 47:1-25

Bernard A, Jensen J, Redding S, Schott P (2007) Firms in international trade. J Econ Perspect 31(3):105-130

Billor N, Hadi S, Velleman PF (2000) BACON: blocked adaptive computationally efficient outlier nominators. Comput Stat Data Anal 34:279-298

Blundell R, Bond S (1998) Initial conditions and moment restrictions in dynamic panel data models. J Econom 87:115-143
Bosworth B, Collins S (2008) Accounting for growth: comparing China and India. J Econ Perspect 22(1):45-66

Brandt L, Van Biesebroeck J, Zhang Y (2012) Creative accounting or creative destruction? Firm-level productivity growth in Chinese manufacturing. J Dev Econ 97:339-351

Cabral LMB (2000) Introduction to industrial organization. MIT Press, Cambridge

Chen M, Guariglia A (2013) Internal financial constraints and firm productivity in China: Do liquidity and export behaviour make a difference? J Comp Econ 41(4):1123-1140

Chen S, Jefferson G, Zhang J (2011) Structural change, productivity growth and industrial transformation. China Econ Rev 22:133-150

Cohen WM, Levinthal DA (1989) Innovation and learning: the two faces of R\&D. Econ J 99:569-596

Dai M, Maitra M, Yu M (2011) Unexceptional exporter performance in China? The role of processing trade. Peking University, Mimeograph

De Loecker J (2007) Do exports generate higher productivity? Evidence from Slovenia. J Int Econ 73:69-98

Del Gatto M, Liberto AD, Petraglia C (2011) Measuring productivity. J Econ Surv 25:952-1008

Ding S, Knight J (2011) Why has China grown so fast? The role of physical and human capital formation. Oxf Bull Econ Stat 73(2):141-174

Ding S, Guariglia A, Knight J (2012) Negative investment in China: financing constraints and restructuring versus growth. Leverhulme Centre for Research on Globalization and Economic Policy, Research Paper 12/01

Disney R, Haskel J, Heden Y (2003) Restructuring and productivity growth in UK manufacturing. Econ J 113:666-694

Dixit AK, Stiglitz JE (1977) Monopolistic competition and optimum product diversity. Am Econ Rev 67:297-308 
Dougherty S, Herd R (2005). Fast falling barriers and growing concentration: the emergence of a private economy in China. OECD Economics Department Working Paper No. 471

Dunning JH (1988) Multinationals, technology and competitiveness. Unwin Hyman, London

Easterly W, Levine R (2001) It's not factor accumulation: stylized facts and growth models. World Bank Econ Rev 15:177-219

Färe R, Primont D (1995) Multi-output production and duality: theory and applications. Kluwer, Boston

Feenstra RC, Li Z, Yu M (2013) Exports and credit constraints under incomplete information: theory and evidence from China. Rev Econ Stat 96(4):729-744

Foster L, Haltiwanger J, Krizan CJ (1998) Aggregate productivity growth: lessons from microeconomic evidence, NBER Working Paper No. 6803

Foster L, Haltiwanger J, Syverson C (2008) Reallocation, firm turnover, and efficiency: selection on productivity or profitability? Am Econ Rev 98:394-425

Greenaway D, Kneller R (2007) Firm heterogeneity, exporting and foreign direct investment. Econ J 117:F134-F161

Griffith R, Redding S, Van Reenen J (2004) Mapping the two faces of $\mathrm{R} \& \mathrm{D}$ : productivity growth in a panel of OECD industries. Rev Econ Stat 86:883-895

Grossman GM, Helpman E (1991) Trade, knowledge spillovers, and growth. Eur Econ Rev 35:517-526

Haggard S, Huang YS (2008) The political economy of private-sector development in China. In: Brandt L, Rawski TG (eds) China's great economic transformation. Cambridge University Press, New York, pp 337-374

Haltiwanger J (1997) Measuring and analyzing aggregate fluctuations: the importance of building from microeconomic evidence. Fed Reserve Bank St. Louis Rev May/June:55-77

Harris R, Moffat J (2012) The contribution of FDI to UK productivity growth. Report to UK Trade and Investment (UKTI)

Harris R, Moffat J (2015) Plant-level determinants of total factor productivity in Great Britain, 1997-2008. J Prod Anal. doi:10. 1007/s11123-015-0442-2

Harris RID, Robinson C (2003) Foreign ownership and productivity in the United Kingdom: estimates for UK manufacturing using the ARD. Rev Ind Organ 22:207-223

Haskel J (2000) What raises productivity? The microeconomics of UK productivity growth, Queen Mary, University of London Research Paper

Hermalin BE (1992) The effects of competition on executive behavior. Rand J Econ 23:350-365

Herrerias MJ, Ordonez J (2012) New evidence on the role of regional clusters and convergence in China (1952-2008). China Econ Rev 23:1120-1133

Hsieh C-T, Klenow PJ (2009) Misallocation and manufacturing TFP in China and India. Q J Econ CXXIV(4):1403-1447

Huang Y (2003) Selling China: foreign direct investment during the reform era. Cambridge University Press, New York

Hymer S (1976) The international operations of national firms: a study of direct foreign investment. MIT Press, Cambridge

Jacobs J (1970) The economy of cities. Jonathan Cape, London

Jacobs J (1986) Cities and the wealth of nations. Penguin, Harmondsworth

Jarreau J, Poncet S (2012) Export sophistication and economic growth: evidence from China. J Dev Econ 97:281-292

Jovanovic B, Nyarko Y (1996) Learning by doing and the choice of technology. Econometrica 64:1299-1310

Klenow PJ, Rodríguez-Clare A (1997) A neoclassical revival in growth economics: Has it gone too far? NBER Macroecon Annu 12:73-103

Lee IH, Rugman A (2012) Firm-specific advantages, inward FDI origins, and performance of multinational enterprises. J Int Manag 18(2):132-146
Levinsohn J, Petrin A (2003) Estimating production functions using inputs to control for unobservable. Rev Econ Stud 70(2):317-341

Li S (2004) The puzzle of firm performance in China: an institutional explanation. Econ Plan 37:47-68

Liao H, Liu X, Wang C (2012) Knowledge spillovers, absorptive capacity and total factor productivity in China's manufacturing firms. Int Rev Appl Econ 26:533-547

Lu D (2010) Exceptional exporter performance? Evidence from Chinese manufacturing firms. University of Chicago, Mimeograph

Manova K, Yu Z (2012) Firms and credit constraints along the valueadded chain: processing trade in China. University of Stanford, Mimeograph

Manova K, Zhang Z (2009). China's exporters and importers: firms, products and trade partners. NBER Working Paper Series No. 15249

Marshall A (1890) Principles of economics. Macmillan, London

Martin R (2008) Productivity dispersion, competition and productivity measurement, CEP Discussion Paper, No. 692, Centre for Economic Performance, LSE, London

Meyer MA, Vickers J (1997) Performance comparisons and dynamic incentives. J Polit Econ 105:547-581

Nickell S (1996) Competition and corporate performance. J Polit Econ 104:724-746

O’Donnell CJ (2015) Using information about technologies, markets and firm behaviour to decomose a proper productivity index. J Econom. doi:10.1016/j.jeconom.2015.06.009

Olley S, Pakes A (1996) The dynamics of productivity in the telecommunications equipment industry. Econometrica 64(6):1263-1297

Pandey M, Dong X (2009) Manufacturing productivity in China and India: the role of institutional changes. China Econ Rev 20:754-766

Romer PM (1986) Increasing returns and long-run growth. J Polit Econ 94:1002-1037

Romer PM (1990) Endogenous technological change. J Polit Econ 98:S71-S102

Roodman D (2009) How to do xtabond2: an introduction to difference and system GMM in Stata. Stata J 9:86-136

Scherngell T, Borowiecki M, Hu Y (2014) Effects of knowledge capital on total factor productivity in China: a spatial econometric perspective. China Econ Rev 29:82-94

Schumpeter JA (1943) Capitalism, socialism, and democracy. George Allen \& Unwin Ltd, London

Sheng Y, Song L (2013) Re-estimation of firms' total factor productivity in China's iron and steel industry. China Econ Rev 24:177-188

Song Z, Storesletten K, Zilibotti F (2011) Growing like China. Am Econ Rev 101:202-241

Tan J, Li S, Xia J (2007) When iron fist, visible hand, and invisible hand meet: firm-level effects of varying institutional environments in China. J Bus Res 60:786-794

Van Beveren I (2012) Total factor productivity estimation: a practical review. J Econ Surv 26(1):98-128

Van Biesebroeck J (2005) Exporting raises productivity in subSaharan African manufacturing firms. J Int Econ 67:373-391

Van Biesebroeck J (2007) Robustness of productivity estimates. J Ind Econ 55(3):529-569

Wang Z, Yu Z (2011) Trade partners, trade products, and firm performance: evidence from China's exporter-importers. GEP Working Paper Series, the University of Nottingham

Windmeijer F (2005) A finite sample correction for the variance of linear efficient two-step GMM estimators. J Econom 126:25-51

Xia J, Li S, Long C (2009) The transformation of collectively owned enterprises and its outcomes in China, 2001-2005. World Dev 37:1651-1662 
Yang C-H, Lin C-H, Ma D (2010) R\&D, human capital investment and productivity: firm-level evidence from China's electronics industry. China World Econ 18:72-89

Yang C-H, Lin H-L, Li H-Y (2013) Influences of production and R\&D agglomeration on productivity: evidence from Chinese electronic firms. China Econ Rev 27:162-178
Yu M (2014) Processing trade, tariff reductions and firm productivity: evidence from Chinese firms. Econ J 125:943-988

Zahra SA, George G (2002) Absorptive capacity: a review, reconceptualization, and extension. Acad Manag Rev 27:185-203 